\title{
The COVID-19 Pandemic: Data Analysis, Impacts, and Future Considerations
}

\author{
Pooya Parvizi ${ }^{1}$, Milad Jalilian $^{2 *}$ (D) Hana Parvizi $^{3}$, Sara Amiri ${ }^{4}$, Hamidreza Mohammad Doust ${ }^{5}$
}

1. School of Engineering, University of Birmingham, Birmingham, United Kingdom

2. Department of Physics, Faculty of Science, Razi University, Kermanshah, Iran

3. Science Department, University of British Columbia, Vancouver, Canada

4. Medical School, Kermanshah University of Medical Sciences, Kermanshah, Iran

5. Department of Physical Education, Tarbiat Modares University, Tehran, Iran

\subsection{9/ijmm.15.1.1}

\section{ABSTRACT}

The 2019 novel coronavirus is another type of known coronaviruses; SARS-CoV-1 and MERS-CoV. The World Health Organization (WHO) has named the virus SARS-CoV-2 and its disease as coronavirus disease 2019 (abbreviated COVID-19). The first case of COVID-19 was reported in December 2019 in Wuhan, China. The epidemiological studies have shown that the disease is transmitted from animal to human, and the spread of the disease from person to person is rapidly expanding. Currently, the most important factor in preventing and controlling the spread of the disease is proper recognition, health care, and control measures. Given the importance of early detection and timely treatment of the disease, the use of nanoscale materials for the production of sensors and drug delivery system can be of great assistance to the researchers. In this context, we aimed to explain the effects of the prevalence of the disease worldwide and consider the different aspects of SARS-CoV-2.

Keywords: COVID-19|rapidly expanding|epidemiological studies|control measures|nanoscale materials

Received: 2020/10/07; $\quad$ Accepted: 2020/12/01; Published Online: 2021/01/10

\begin{tabular}{|c|c|}
\hline Corresponding Information: & $\begin{array}{l}\text { Milad Jalilian, Department of Physics, Faculty of Science, Razi University, Kermanshah, Iran } \\
\text { Email: jalilianm70@gmail.com }\end{array}$ \\
\hline (c) $\underset{\mathrm{BY}}{\mathrm{B}} \mathrm{\textrm {NC }}$ & $\begin{array}{l}\text { This is an original open-access article distributed under the terms of the Creative Commons Attribution-noncommercial } 4.0 \text { International License which } \\
\text { distribution of the material just in noncommercial usages with proper citation. }\end{array}$ \\
\hline
\end{tabular}

Use your device to scan and read the article online

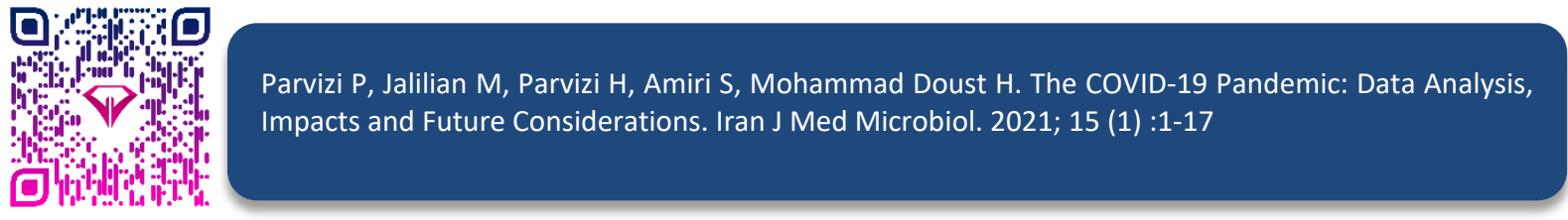

Download citation: BibTeX | RIS I EndNote I Medlars L ProCite | Reference Manager | RefWorks

Send citation to: $8 \underline{\text { Mendeley }} \mathbf{2}$ zotero $\mathbb{H}_{\text {RefWorks }}$

\section{Introduction}

Coronaviruses are a large family of viruses that contain four known types of alpha, beta, gamma, and delta coronaviruses that exist in animals such as camels, bats, etc. They have the ability to infect humans (1-3). SARS-CoV-1 spread in 2002 in 29 countries caused illness in 8096 cases among whom 774 cases died (4). A few years after the advent of SARS-CoV-1, the MERS-CoV, first appeared in Saudi Arabia in 2012 in a 60-year-old man with severe lung inflammation and spread to 27 countries in the Middle
East, North Africa, Europe, Eastern Asia, and the United States. It infected 2519 and killed 866 people (5). Recently, a new type of coronavirus in human that has led to COVID-19 spread first in Wuhan, China, and after a few weeks to various countries all around the world, and it is still distributing. This type of coronavirus along with SARS-CoV- 1 and MERS-CoV is a beta type of coronaviruses $(6,7)$. The researchers initially estimated bats as the host of the virus by sampling seven patients and bats, with $96.2 \%$ of the 
shared genome sequence, moreover, the subsequent research confirmed the pangolin-genome similarity to the SARS-CoV-2 to potentially make this animal as virus host $(8,9)$.

\section{Expanding COVID-19 in the World}

According to the WHO report No.163 on July 1, 2020, COVID-19 has a worldwide population of 10357662, of which 508055 have died. Figure 1 shows the confirmed cases and deaths of COVID-19 in the countries of China, Iran, the Republic of Korea, Italy, Spain, France, the United Kingdom, Germany, the United States of America, and Japan from the date of the first WHO report to July 1, 2020. The first confirmed cases were reported in China in December, Japan on January 15, the Republic of Korea on January 20, Italy on February 5, Iran on February 19, the United
States of America on January 23, Spain on February 1, France on January 25, the United Kingdom on February 1, and Germany on January 28 (10). As can be seen on the figure, the highest deaths and confirmed cases were reported in the United States of America. Japan and the Republic of Korea were the first to report COVID-19 in the mid-January; they had the lowest incidence compared to the other countries. The outbreak in China has been stable since late February, and the country has been able to control the disease. The results showed that China, Japan, and Korea have been able to properly identify, diagnose, and treat patients. They have also well implemented community control measures. In fact, this proper performance can be due to the lessons they learned from SARS-CoV-1 and the pandemic flu $(11,12)$.

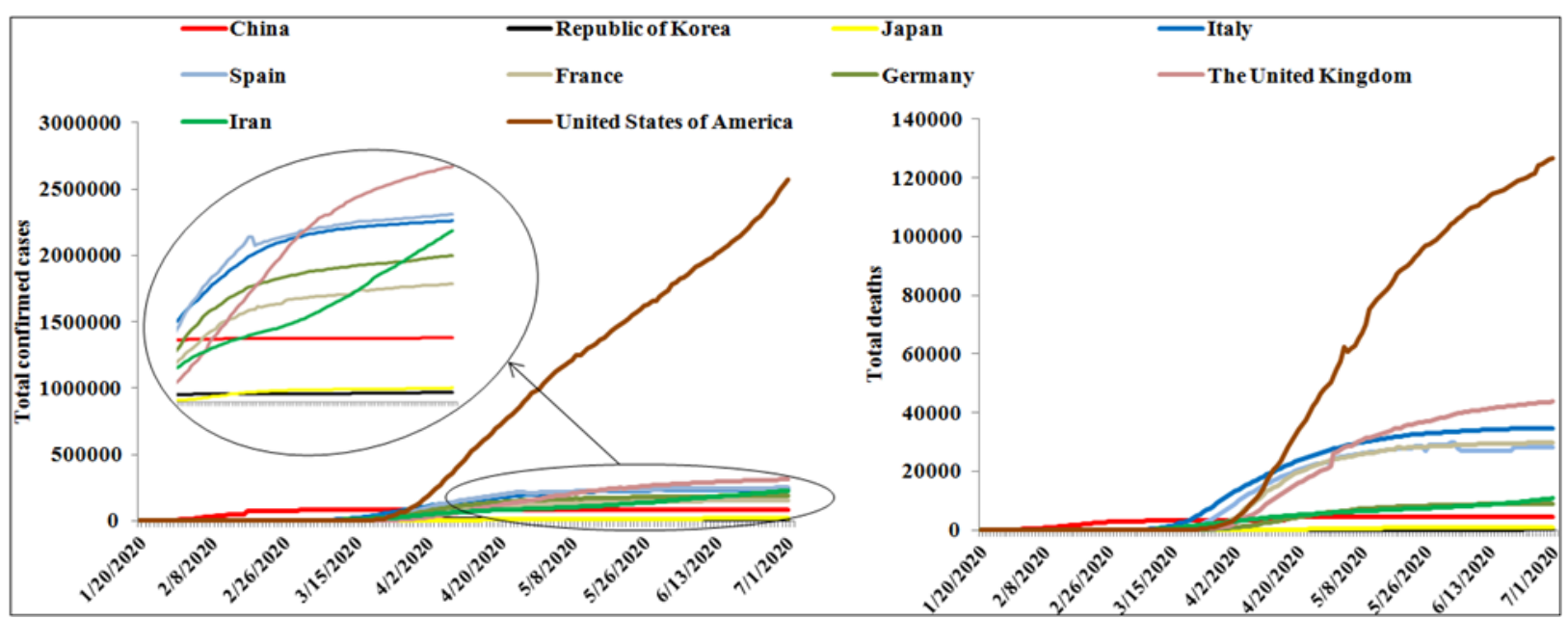

Figure 1. Total confirmed cases and total deaths of COVID-19 in China, the Republic of Korea, Italy, Iran, Japan, the United States of America, Spain the United Kingdom, France, and Germany by July 1, 2020. Notes: According to the WHO report No.28, since February 17, 2020, cases with clinical diagnosis have been added along with laboratory tests to provide the reports. (Data source: World Health Organization)

Figure 2 shows the case fatality rate (CFR) curve in different countries from March 9 to July 1, 2020. The CFR globally as of July 1,2020 , was $4.90 \%$. The CFRs in France, Italy, the United Kingdom, Spain, China, Japan, and the United States of America were $18.93 \%, 14.45 \%, 13.98 \%, 11.37 \%, 5.45 \%, 5.20 \%$, $4.91 \%$, respectively, which were higher than the global rate while CFRs in Iran, Germany, and the Republic of Korea were 4.75\%, 4.61\%, and, 2.19\%, respectively, which were lower than the global rate. It should be noted that the difference in CFRs between different countries may be affected by testing programs, population age, and underlying diseases $(13,14)$. Of course, the policy of countries in expressing the statistics, how to perform the control measures, medical facility, people's awareness, and observance of the health principles may have profound effects on the CFRs.

The confirmed cases and deaths of COVID-19 in different regions of the world by July 1, 2020 are shown in Figure 3 . The Americas and the African regions have the highest and the lowest confirmed cases and deaths, respectively. The Eastern Mediterranean region has the lowest CFR (2.31\%) and the European region has the highest CFR (7.25\%) in the world. Region of the Americas accounts for $50.38 \%$ of total confirmed cases and $38.94 \%$ of total deaths due to COVID-19 as per global statistics (10). 


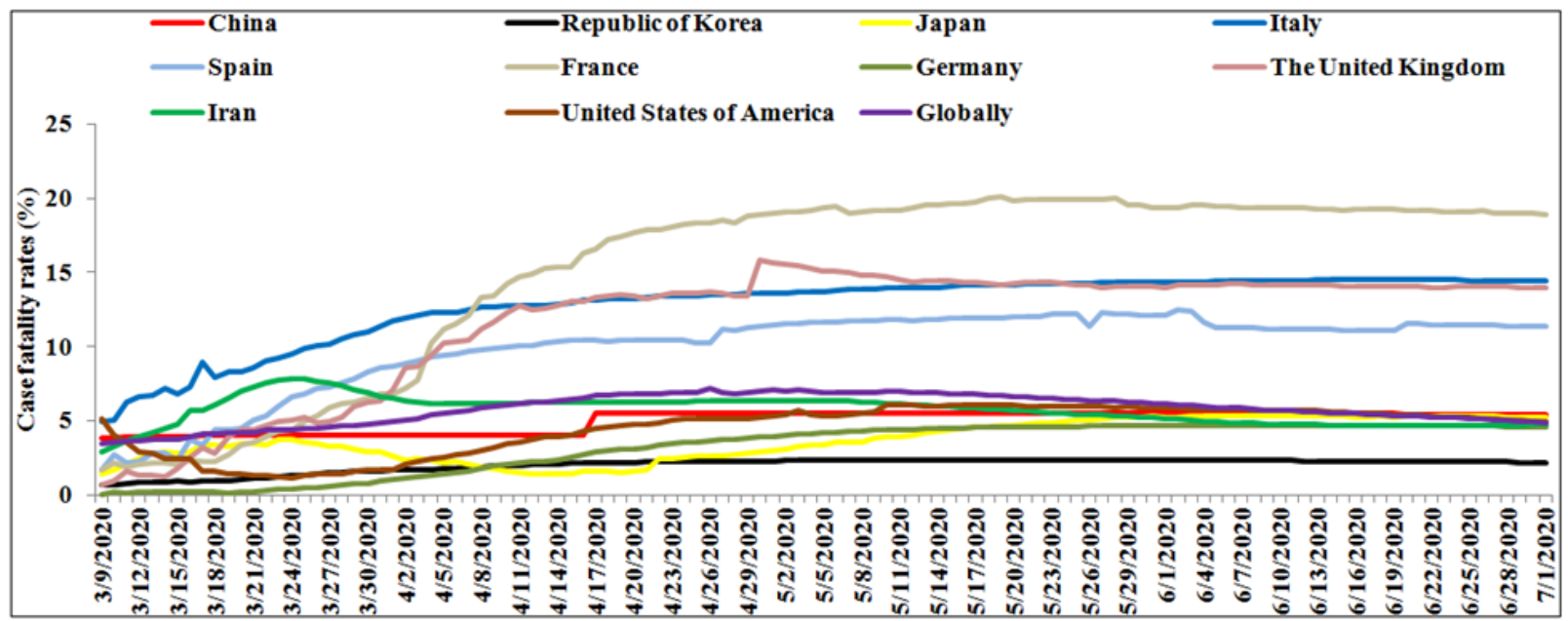

Figure 2. CFRs (\%) of COVID-19 in France, Italy, the United Kingdom, Spain, Iran, China, the United States of America, the Republic of Korea, Germany, Japan and Globally from March 9 to July 1, 2020. (Data source: World Health Organization).
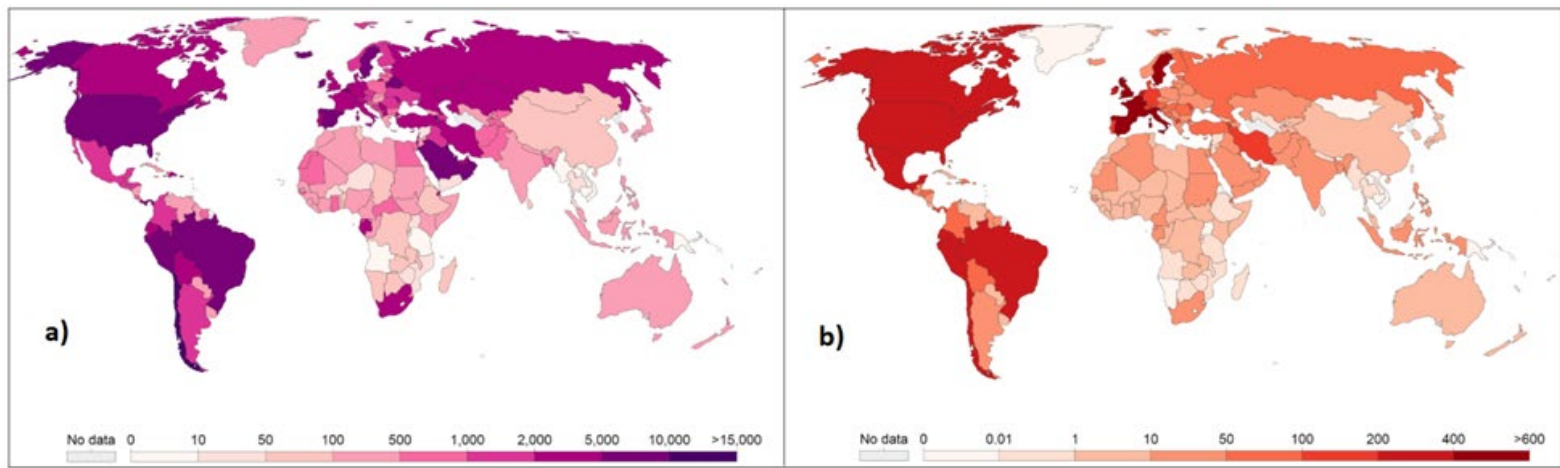

Figure 3. Total confirmed COVID-19. a) cases and b) deaths per million people by July 1, 2020 (15).

Viral diseases have always been a major threat to the world and endangered human health (16). Table 1 shows the statistics on several types of viral diseases: The CFRs were $77.8 \%$ for Marburg disease (highest CFR), 41.46\% Ebola, 57\% Hendra, 9.6\% SARS-CoV-1, $0.07 \%$ H1N1 Flu, 34.4\% MERS-CoV, and 4.90\% COVID-
19 as of July 1 . An important point about the types of viral diseases that the world has gone through or is involved in, is that it can raise the level of readiness of countries and preparation to fight against infectious diseases in the future (17).

Table 1. Comparison between different viruses.

\begin{tabular}{|c|c|c|c|c|c|c|}
\hline Virus & Year identified & Cases & Deaths & Case fatality rate (\%) & $\begin{array}{l}\text { Number of } \\
\text { countries }\end{array}$ & Ref. \\
\hline Marburg & $1967-2014$ & 587 & 457 & $77.8 \%$ & 9 & (18) \\
\hline Ebola & $1967-2018$ & 31095 & 12950 & $41.64 \%$ & 15 & (19) \\
\hline Hendra & $1994-2013$ & 7 & 4 & $57 \%$ & 1 & (20) \\
\hline SARS-CoV-1 & $2002-2003$ & 8096 & 774 & $9.6 \%$ & 29 & (4) \\
\hline H1N1 Flu & 2009-2018 & $100.5 \mathrm{M}$ & 75000 & $0.07 \%$ & 1 & (21) \\
\hline MERS-CoV & $2012-2020$ & 2519 & 866 & $34.4 \%$ & 27 & (5) \\
\hline COVID-19 & $\begin{array}{l}\text { December 2019- } \\
\text { July } 1,2020\end{array}$ & 10357662 & 508055 & $4.90 \%$ & 213 & (10) \\
\hline
\end{tabular}

Research results on 44627 confirmed cases of COVID-19 in China in different age groups showed that the highest CFR for COVID-19 (14.8\%) was over 80 years old (Figure 4).
There were also no reports of deaths between the ages of 0 and 9 years. The CFR was $2.8 \%$ for males and $1.7 \%$ for females. The results showed that in addition to the elderly, 
those with underlying medical conditions such as hypertension, cancer, cardiovascular disease, diabetes, pulmonary infections, and other chronic diseases are at higher risk of death $(22,23)$. Also, the CFRs in Italy between the ages of 60-69, 70-79, and $80+$ years were reported to be $3.5 \%, 12.8 \%$, and $20.2 \%$, respectively (13).

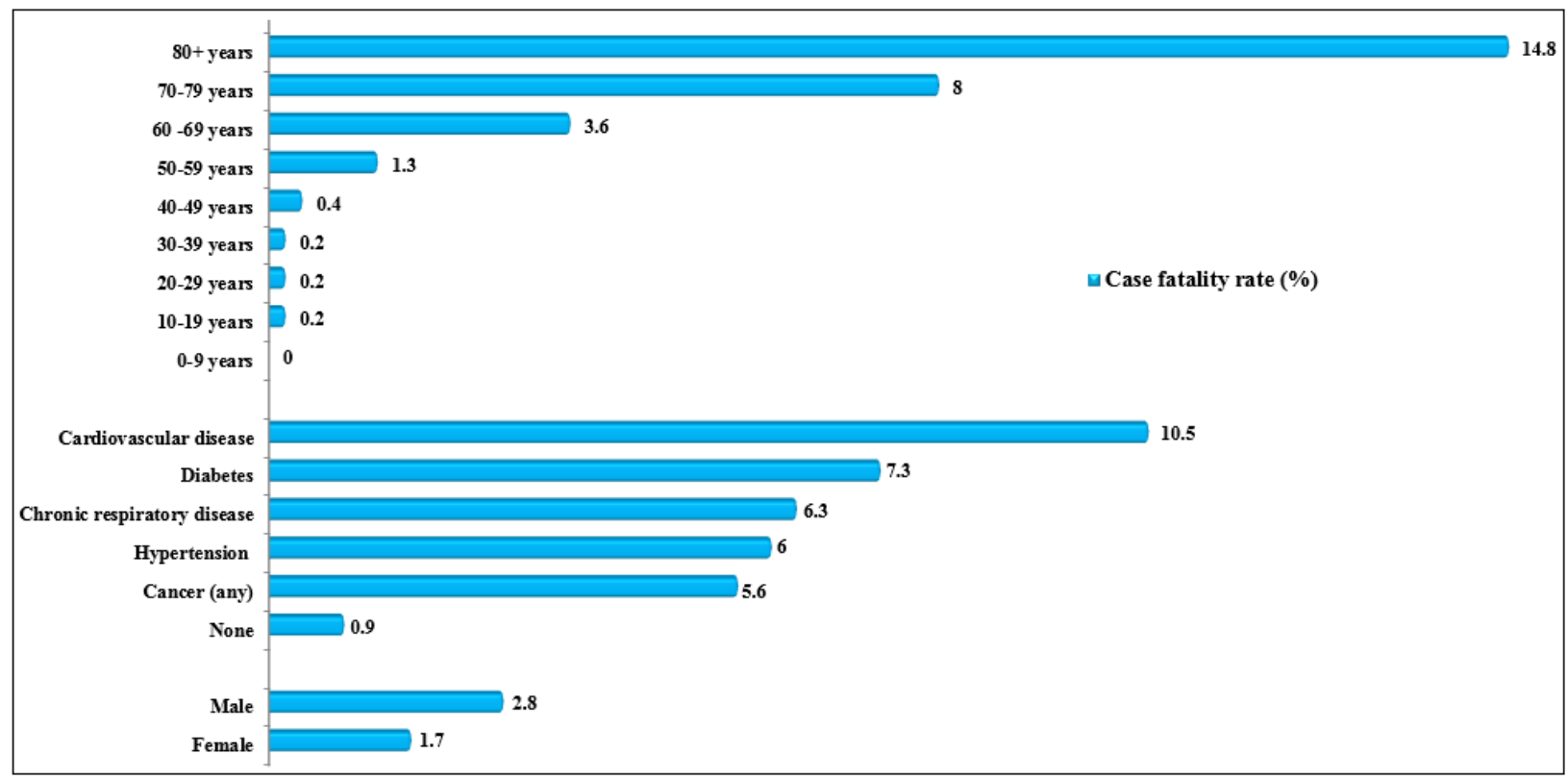

Figure 4. COVID-19 CFRs in different groups

In SARS-CoV-1 disease that spread in China in 2002, the CFRs were $1 \%, 6 \%, 15 \%$, and $50 \%$ in the age groups 0-24, 25-44, 45-64 and over 64 years, respectively (24) and also the highest CFR for MERS-CoV was in over 50 years of age (5). Some similarities and differences between COVID-19 and SARS-CoV-1 and MERS-CoV are presented in Table 2.

Table 2. Comparison between COVID-19, SARS, and MERS (10, 25-28).

\begin{tabular}{|c|c|c|c|}
\hline & SARS-CoV-1 & MERS-CoV & COVID-19 \\
\hline First case & 16 November 2002 in China & $\begin{array}{c}\text { September } 2012 \text { in Saudi } \\
\text { Arabia }\end{array}$ & December 2019 in China \\
\hline Pathogen & SARS-CoV-1 & MERS-CoV & SARS-CoV-2 \\
\hline Host & Rhinolophus sinicus & Camel & Rhinolophus affinis, Pangolin \\
\hline Virus type & RNA virus & RNA virus & RNA virus \\
\hline Species pathogen & beta coronavirus & beta coronavirus & beta coronavirus \\
\hline Incubation & 1-4 Days & 4-7 Days & 3-7 Days \\
\hline Male-female patient ratio & $1: 1.25$ & $2.2: 1$ & $2.7: 1$ \\
\hline Clinical symptoms & $\begin{array}{l}\text { Fever, cough, myalgia, dyspnea, and } \\
\text { diarrhea }\end{array}$ & Fever, cough, dyspnea & Fever, cough, dyspnea, Fatigue \\
\hline
\end{tabular}

\section{Symptoms of COVID-19}

Primary symptoms that are more prevalent among COVID-19 patients include dry cough, fever, fatigue, and dyspnea and some clinical observations include symptoms such as sneezing, sore throat, diarrhea, and myalgia (28). People normally may confuse the symptoms of COVID-19 with other diseases such as influenza, colds, and seasonal allergies that make them go to the hospitals. At this time, the experienced and skilled physicians can make the right diagnosis and choose proper next steps for the treatment using the patient's symptoms. Table 3 shows the clinical symptoms in males and females of different age groups who got infected with SARS-CoV-2. 
Table 3. Clinical characteristics of patients infected with SARS-CoV-2.

\begin{tabular}{|c|c|c|c|c|c|c|c|}
\hline Ref. & (29) & (30) & (31) & (28) & (32) & (33) & (34) \\
\hline Sex & $\begin{array}{l}459 \text { Male- } \\
640 \text { Female }\end{array}$ & $\begin{array}{l}19 \text { Male- } \\
32 \text { Female }\end{array}$ & $\begin{array}{l}67 \text { Male- } \\
32 \text { Female }\end{array}$ & $\begin{array}{l}30 \text { Male- } \\
11 \text { Female }\end{array}$ & $\begin{array}{l}75 \text { Male- } \\
63 \text { Female }\end{array}$ & $\begin{array}{l}71 \text { Male- } \\
69 \text { Female }\end{array}$ & $\begin{array}{l}32 \text { Male- } \\
37 \text { Female }\end{array}$ \\
\hline $\begin{array}{l}\text { Age, Median (range) } \\
- \text { yrs }\end{array}$ & $47(35-58)$ & $45(34-51)$ & $55(21-82)$ & $49(41-58)$ & $56(42-68)$ & $57(25-87)$ & $42(35-62)$ \\
\hline Fever & $966(87.9 \%)$ & $43(84.3 \%)$ & $82(83 \%)$ & $40(98 \%)$ & $136(98.6 \%)$ & $\begin{array}{l}110 / 120 \\
(91.7 \%)\end{array}$ & $60(78 \%)$ \\
\hline Cough & $744(67.7 \%)$ & $38(74.5 \%)$ & $81(82 \%)$ & $36(76 \%)$ & $55(59.4 \%)$ & $90 / 120(75 \%)$ & $38(55 \%)$ \\
\hline Fatigue & $419(38.1 \%)$ & $22(43 \%)$ & NA & $18(44 \%)$ & $96(69.6 \%)$ & $90 / 120(75 \%)$ & $29(42 \%)$ \\
\hline Dyspnea & $204(18.6 \%)$ & $11(21.6 \%)$ & $31(31 \%)$ & $22 / 40(55 \%)$ & $43(31.2 \%)$ & $44 / 120(36.7 \%)$ & $20(29 \%)$ \\
\hline Myalgia & $163(14.8 \%)$ & $6(11.8 \%)$ & $11(11 \%)$ & $18(44 \%)$ & $48(34.8 \%)$ & NA & $21(30 \%)$ \\
\hline Headache & $150(13.6 \%)$ & $5(9.8 \%)$ & $8(8 \%)$ & $3 / 38(8 \%)$ & $9(6.5 \%)$ & NA & $10(14 \%)$ \\
\hline Anorexia & NA & NA & NA & NA & $55(39.9 \%)$ & $17 / 139(12.2 \%)$ & $7(10 \%)$ \\
\hline Expectoration & $367(33.4 \%)$ & NA & NA & $11 / 39(28 \%)$ & $37(26.8 \%)$ & NA & NA \\
\hline Diarrhea & $41(3.7 \%)$ & $4(7.8 \%)$ & $2(2 \%)$ & $1 / 38(3 \%)$ & $14(10.1 \%)$ & $18 / 139(12.9 \%)$ & $10(14 \%)$ \\
\hline Dizziness & NA & $7(13.7 \%)$ & $9(9 \%)$ & NA & $13(9.4 \%)$ & NA & NA \\
\hline Vomiting & $55(5 \%)$ & $3(5.9 \%)$ & $1(1 \%)$ & NA & $5(3.6 \%)$ & $24 / 139(17.3 \%)$ & NA \\
\hline Rhinorrhoea & NA & $3(5.9 \%)$ & $4(4 \%)$ & NA & NA & NA & NA \\
\hline Pharyngalgia & $153(13.9 \%)$ & NA & $5(5 \%)$ & NA & $24(17.4 \%)$ & NA & NA \\
\hline
\end{tabular}

\section{Prevention and Treatment of the Disease}

Experimental results have shown that the virus persists in aerosols for an average of two and a half hours, on surfaces such as plastic and stainless steel for more than three days, on copper for more than four hours, and on cardboard for one day. This causes the virus to spread rapidly and infect more people (35). Among measures to prevent the infection with this new type of coronavirus include: 1) Frequent hand washing with soap and water or alcohol-based solutions especially after contact with contaminated devices, 2) Cover mouth and nose when sneezing and coughing and avoid touching eyes, 3) No contact with animals, 4) Fully cooking of foods, 5) Use of face mask, 6) Keep distance with persons, and 7) Avoid public and overcrowded places. Identifying and isolating patients, and providing inter-individual health education reduces the incidence of the disease (3638). Due to the rapid spread of the disease in society and its infectious rate, it has created psychological pressure among the general public and patients. The immune system, which plays a key role in counteracting the new coronavirus, would be weakened by the effects of this stress. The stress can reduce natural killer cell activity, lymphocyte proliferation and populations, and antibody production, and reactivates latent viral infections (39, 40). It should be noted that proper management of stress using psychological techniques and nutrition programs can have a significant effect on the fight against COVID-19. Using vitamins A, B, C, D, E, and folic acid, as well as trace elements zinc, selenium, iron, and copper are among the ways to boost the immune system to defense against viral infections (41-43). Nacetylcysteine, as an antioxidant supplement, plays an important role in enhancing immune function in preventing and treating viral infections $(44,45)$. Medicinal plants are of great importance in the fight against viruses because of their antiviral properties (46). The beneficial effects of using Isatis indigotica (47) and Torreya nucifera (48) against SARS-CoV-1 have been reported before. At present, the treatment and reduction of COVID-19 infection using antiviral drugs such as nucleoside analogues (e.g., Favipiravir, also known as T-705 and ribavirin) and HIV protease inhibitors are currently being studied $(49,50)$. The beneficial effects of chloroquine and hydroxychloroquine in the treatment of patients have also been reported $(51,52)$. Recent research has shown that the Angiotensin-converting enzyme 2 (ACE2) receptor inhibition by adding a genetically modified variant of ACE2, called human recombinant soluble ACE2 (hrSACE2) might be used in treating patients with COVID-19 at the early stages of the disease (53). It should be noted that the prescription of these drugs is based on the physician diagnosis and should be used under their medical supervision. One of the factors that can influence the transmission of the virus is the climatic conditions. Research on this subject is being carried out and the current results showed that the effects of high temperature and 
humidity can reduce the transmission of the coronavirus $(54,55)$.

\section{The Phases of the Pandemic}

Over the past years, zoonotic viral diseases have always been a major threat to human health, and coronaviruses are one of the most important ones (56). COVID-19 is rapidly expanding globally, as announced by the WHO on March 11, 2020, it has become a global pandemic (57). In fact, the announcement of this situation causes countries to enter a new phase of health care to tackle this disease and to raise awareness of the communities and measures needed to rapidly develop vaccine. Programs and resources to cope with COVID-19 expressed by the Centers for Disease Control and Prevention $(C D C)$ and the WHO are similar to those of pandemic influenza. The chains of the global influenza pandemic phases include the research phase (detection of new disease), diagnosis phase (identification of cases worldwide, virus characteristics showing the potential of rapid humanto-human transmission and control measures for the reported cases), initiation phase (worldwide onset of disease wave, the continuous implementation of casecontrol measures and routine protective measures such as hand washing, enhanced monitoring to detect added cases to determine the time of action and reducing social gatherings), acceleration phase (acceleration of the epidemic wave, the immediate onset of social gatherings reduction measures such as school closures, cancelling social events, self-isolation and quarantine), the deceleration phase (reducing the epidemic wave by reducing the incidence, and planning to suspend or reduce control measures in the community), and the preparation phase (preparations for the next wave of epidemics, infrastructure improvements, protocols for detecting subsequent waves, and evaluation of the response to the first wave) (58-60).

\section{The effects of Coronavirus on the Economy}

Infectious diseases have always had a negative impact on the world economy. For example, the estimates showed the impact of SARS-CoV-1 on the gross domestic product (GDP) in Hong Kong, Canada and Singapore at $\$ 3.7, \$ 3.2-6.4$, and $\$ 4.9$ billion, respectively (61). Estimates of the influenza epidemic effect in Belgium, France, the Netherlands, and the United Kingdom showed an average drop of $2.5 \%$ in their GDP (62). The \$2.2 billion GDP loss in Guinea, Liberia, and Sierra Leone in 2015 was due to Ebola (63). COVID-19 is currently expanding globally and is affecting the economies of countries and the factors such as the period of development, infected cases and, CFRs can surely pose a significant threat to the health and economy of the countries (64).

\section{Nanotechnology and Coronaviruses}

The importance of nanoscale materials in medical sciences in the diagnosis and treatment has always been of interest to researchers (65). Viruses are one of the types of microbes that are nanometer-sized and their rapid detection can prompt the onset of disease treatment. Therefore, nanoscale materials such as metallic nanoparticles, quantum dots, and carbon nanostructures can play an important role in the timely detection of viruses. Gold and silver nanoparticles have always been of interest to researchers in the field of disease diagnosis and treatment due to their unique optical, physical, and chemical properties (66). Gold nanoparticles were used to detect and diagnosis of patients with SARSCoV-1 by colorimetric and electrochemical methods in 5 and 120 minutes $(67,68)$. In the discussion of nanoparticle-based treatments, research work on MERS-CoV suggests that PIH-AuNRs, a gold nanorod complex, can induce disease treatment (69). Nanomedicine research shows the importance and association between nanoparticles and chloroquine for the treatment of COVID-19 (70).

\section{Conclusions}

Due to the rapid spread of COVID-19 worldwide and the increase in the number of cases, the WHO declared it as a global pandemic on March 11, 2020. The transmission rate of COVID-19 from human to human is higher than MERS-CoV and SARS-CoV-1, but it has a lower CFR. Some of the most important factors in preventing SARS-CoV-2 outbreak are community control measures and people's health care. In the face of the high prevalence of pandemic diseases, due to the constant availability of health facilities in countries, it should be noted that if the peak of disease prevalence is higher than the level of health facilities, patients care may become problematic in that country. During this time, preventive and control measures such as social distancing and government restrictions on community gatherings and closing centers unrelated to the basic needs can help to flatten the curve, reduce the disease waves, and reduce the pressure on the health care system. It is important to note that the executive programs of countries that have been able to control the disease and countries at the peak of the disease can have important lessons for countries that are in the initial stages of the disease. In fact, researchers in the affected countries can prevent catastrophic events in other countries by publishing their findings in the field of treatments and control measures. In the field of treatments, while research is quickly undergoing to develop the vaccine, some antiviral drugs, and dietary supplements are currently being used to treat COVID19. Use of dietary supplements has two aspects: 1 ) Strengthening the body to speed up the disease 
treatment for the individuals who have already been diagnosed with the infection, and 2) Strengthening the immune system of healthy individuals so that their risk of catching the disease will be decreased. One way that can be of great help to the diagnosis and treatment of coronaviruses is to use nanoscale materials that are used in the drug delivery systems and the production of sensors. SARS-CoV-2 has spread to all regions of the world and has led to challenges.
Production and introduction of the vaccine, as well as climate change, are two scenarios that have been put forward along with other measures to reduce and control the COVID-19 incidence

\section{Conflict of Interest}

The authors declared no conflicts of interest related to this work. 


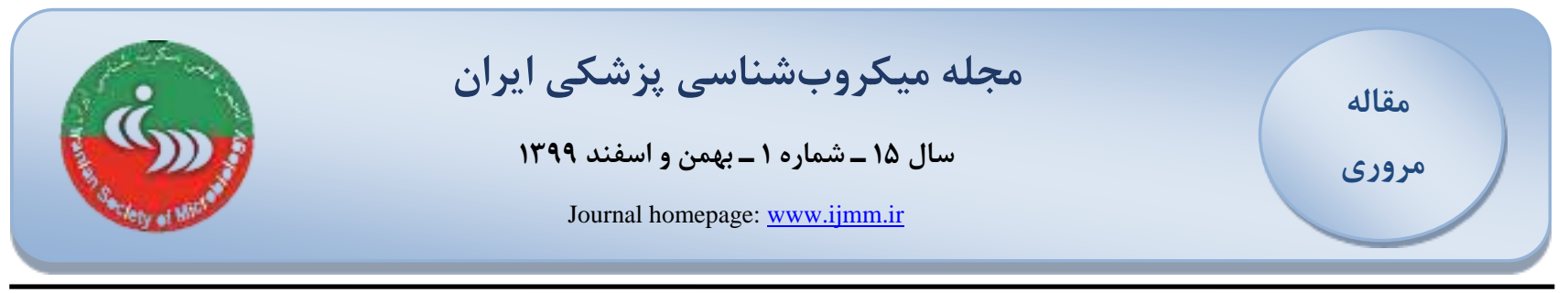

\title{
ֶاندمى COVID-19: آناليز دادهها، اثرات و ملاحظات آينده
}

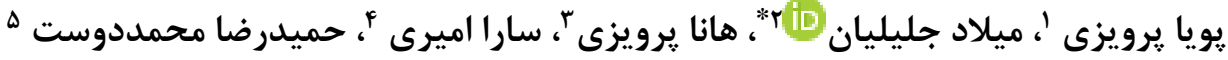

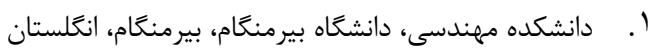

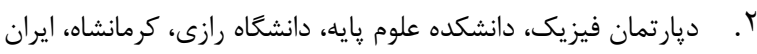

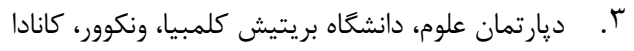

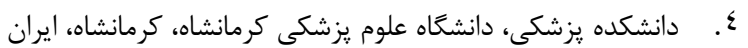

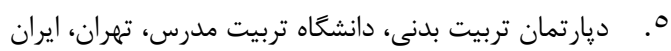

\begin{tabular}{|c|c|}
\hline جـكيده & اطلاعات مقاله \\
\hline 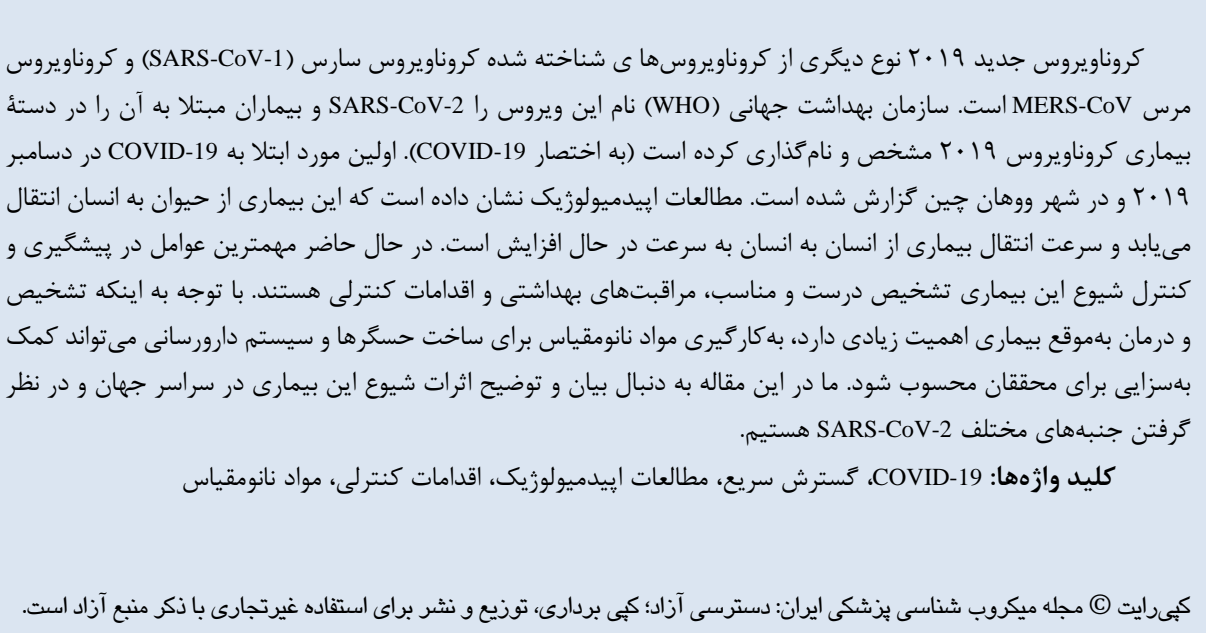 & 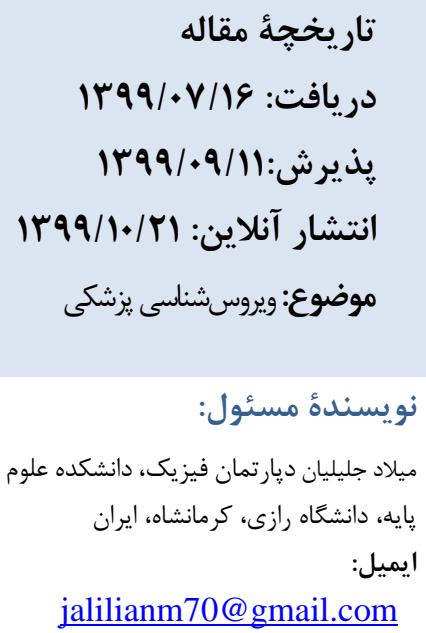 \\
\hline
\end{tabular}

مقدمه

19 كرديده است ابتدا در ووهان جين و يّ از جند هفته به به كشورهاى

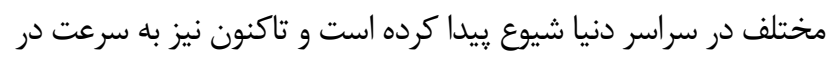
حال گسترش است. اين نوع كروناويروس همانند MERS-CoV

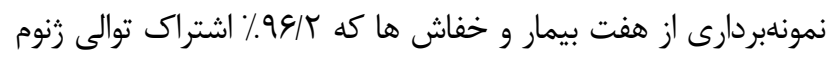

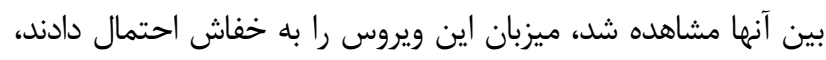

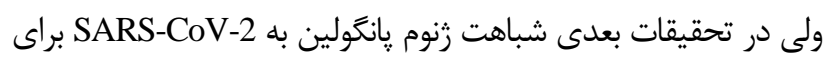

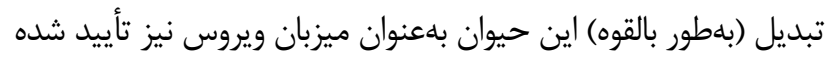

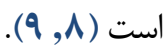

كروناويروسها خانواده بزرگى از ويروسها هستند كه شامل جهار نوع آلفا، بتا، كاما و دلتا كروناويروس هستندا. مانند شتر، خفاش و غيره وجود دارند و مىتوانند انسانها را آلوده كنند

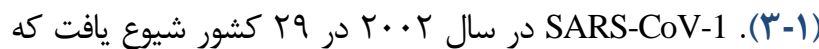

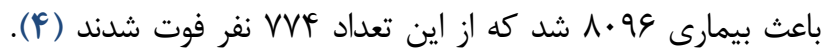

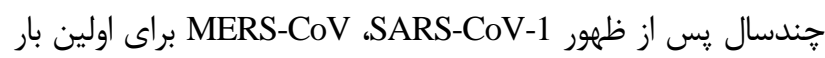

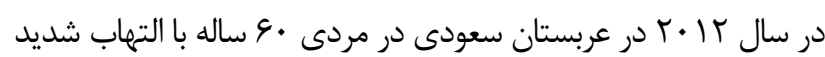
ريوى نمايان گرديد و دامنه كسترش آن به TV كشور در مناطق

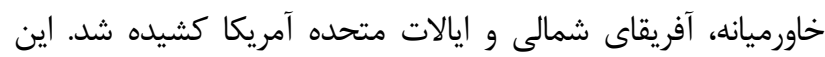

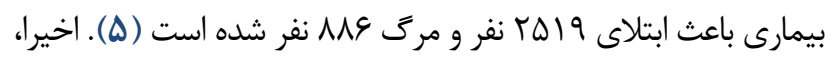

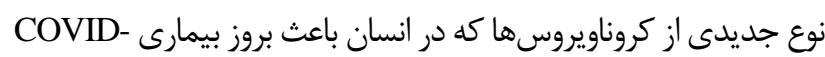


شكل 1 مشاهده مى گردد، بالاترين ميزان مرى و مير و موارد ابتلاى

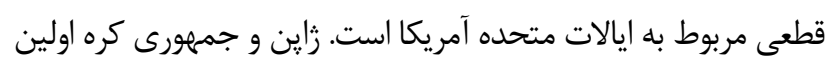

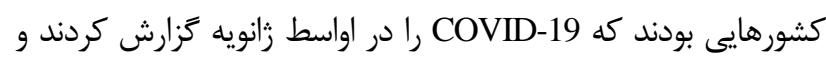
در مقايسه با ساير كشورها كمترين ميزان شيوع بيمارى را داشتند.

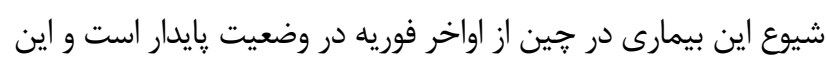

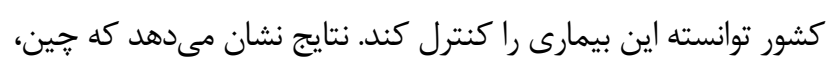

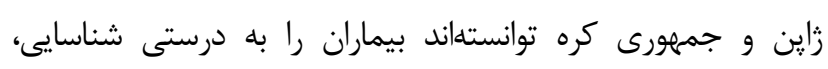

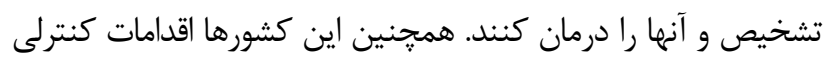

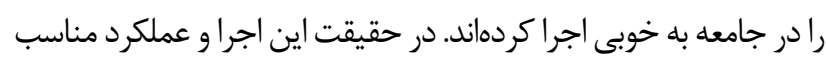

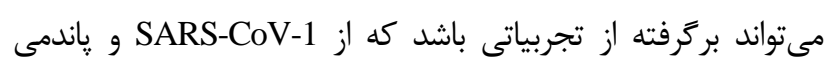

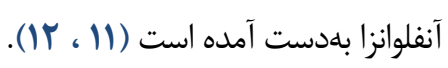

\section{شيوع و كسترش COVID-19 در دنيا}

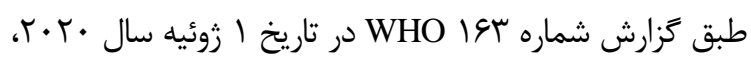

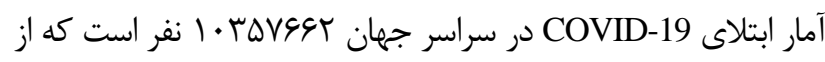

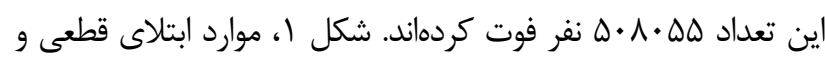

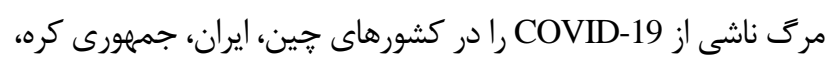

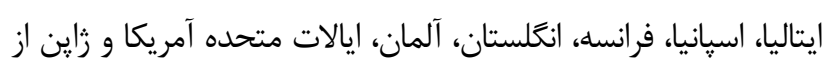

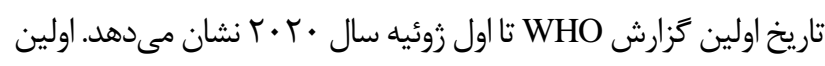

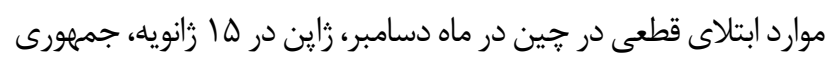

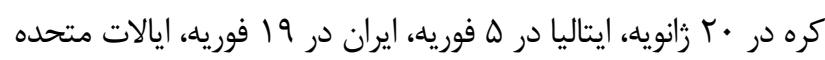

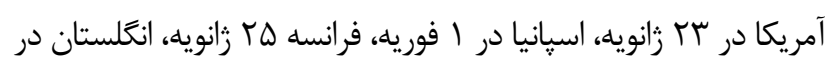

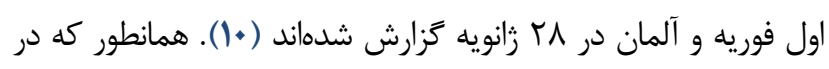

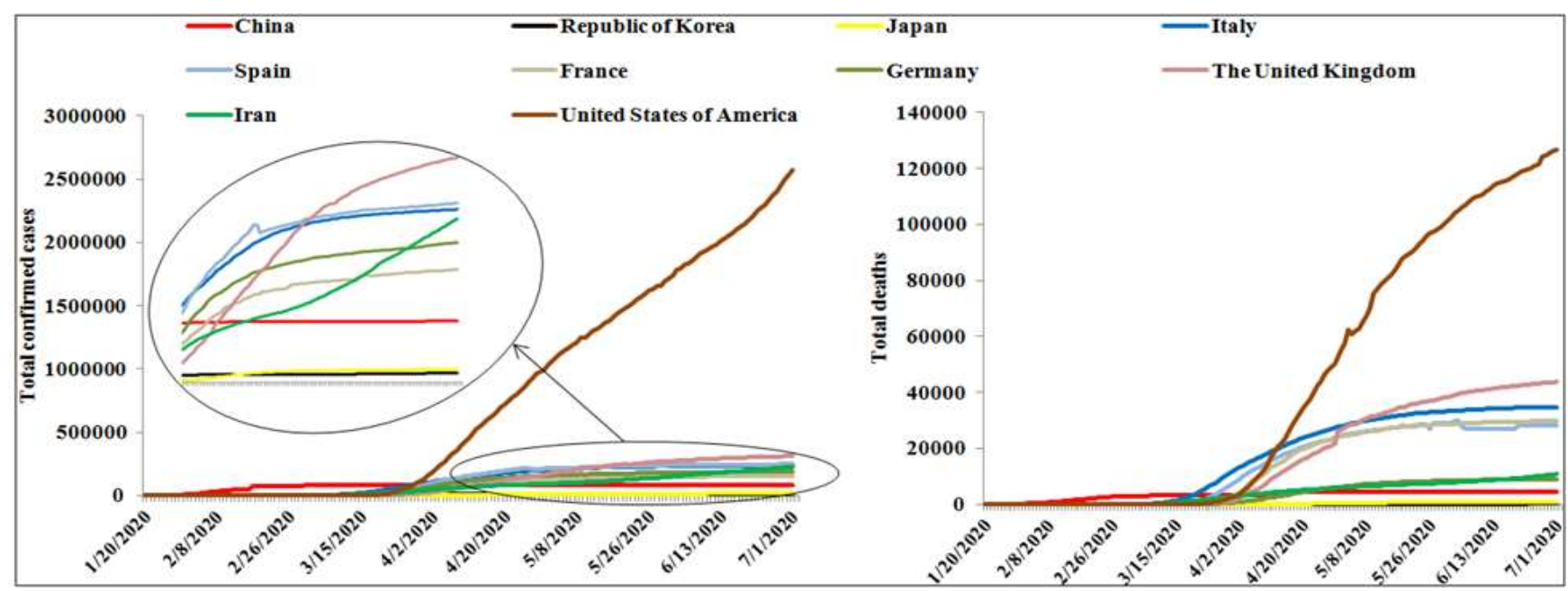

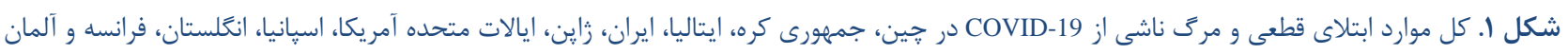

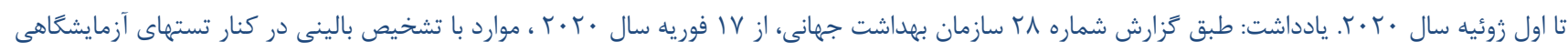

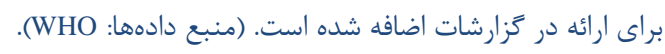

در بيان آمار، نحوه پِيادهازى اقدامات كنترلى، امكانات يزشكى،

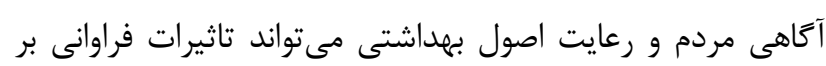
ميزان تلفات داشته باشد. موارد ابتلاى قطعى و مرى ناشى از COVID-19 در مناطق

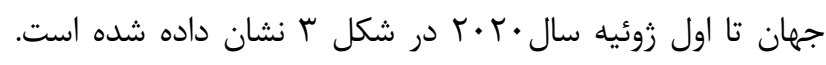

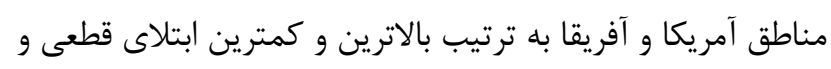

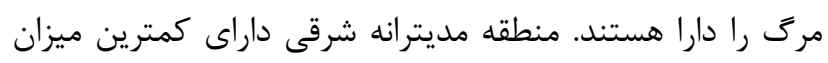

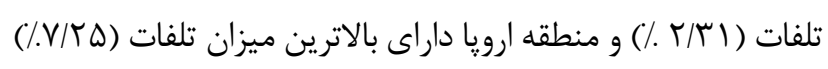

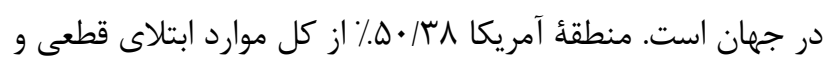

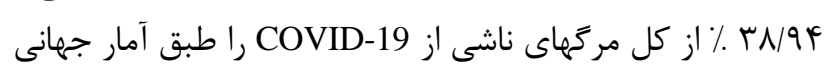

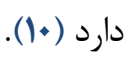

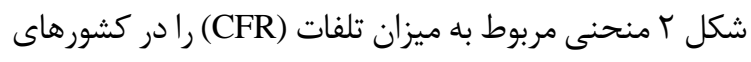

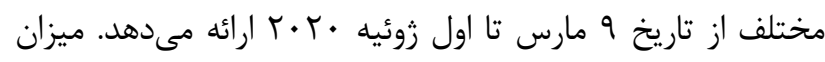

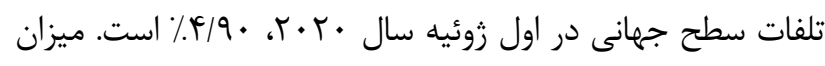

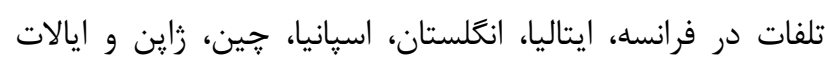

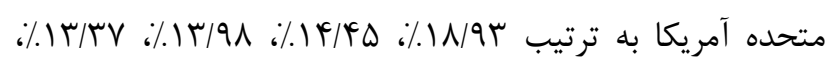

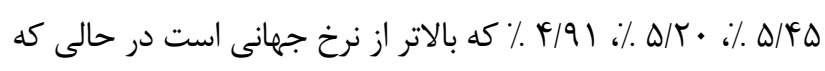

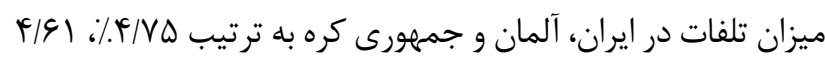

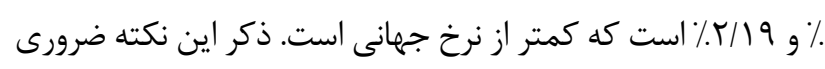

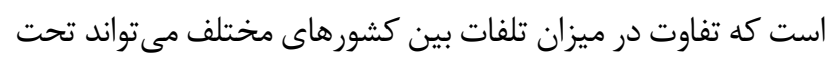

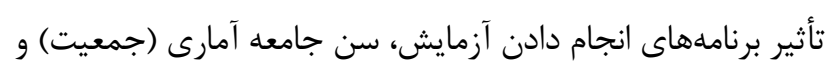

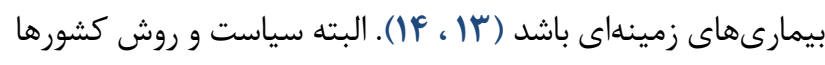




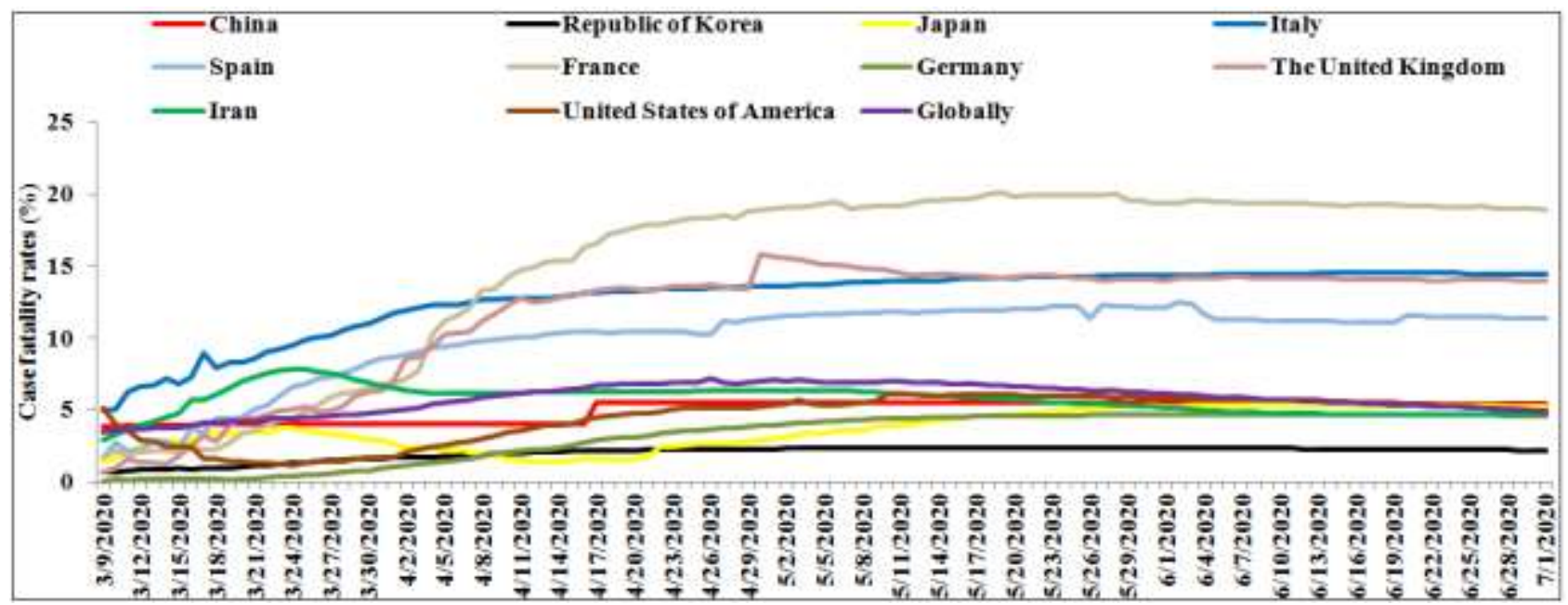

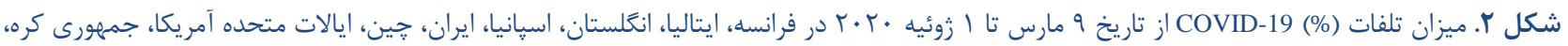

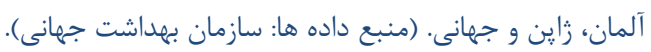

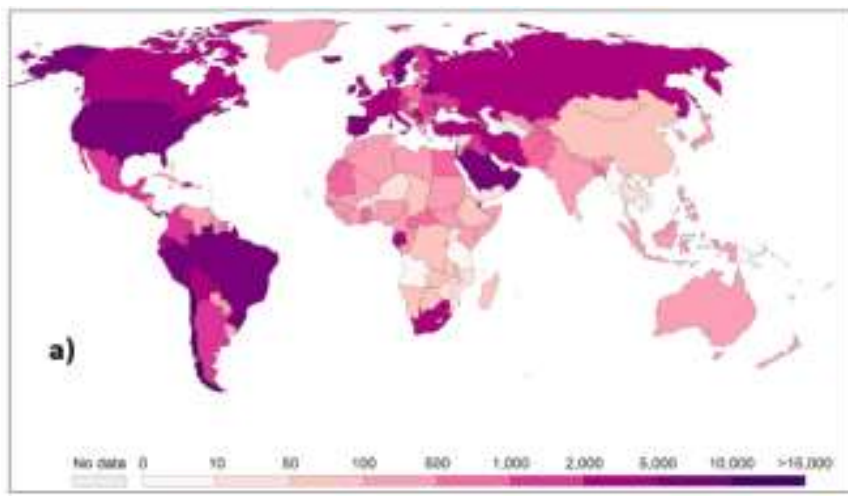

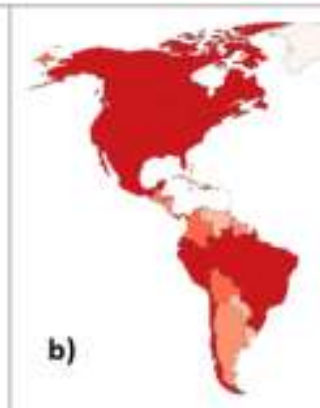

not o

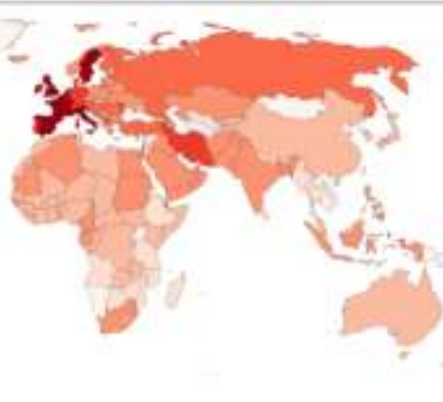

شكل

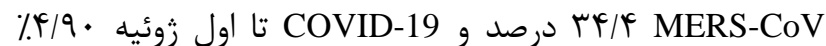
كزارش شدهاند. نكته مهم در مورد انواع بيمارىهاى ويروسى كه دانه

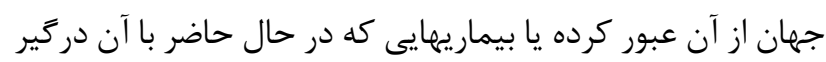

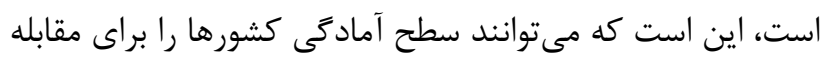

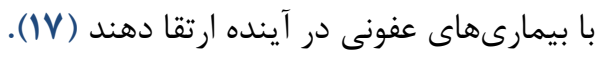

بيمارىهاى ويروسى هميشه تهديدى بزرى براى جهان

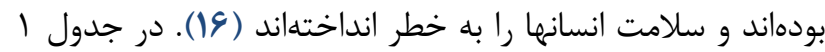

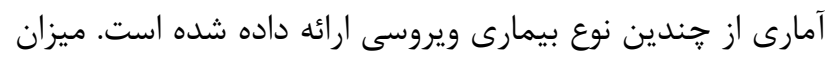

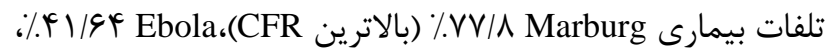

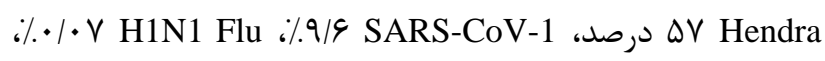

جدول 1. مقايسه بين ويروسهاى مختلف

\begin{tabular}{|c|c|c|c|c|c|c|}
\hline مراجع & تعداد كشورها & ميزان ثلفات (٪) & 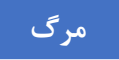 & 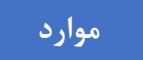 & سال شناسايى & ويروس \\
\hline$(\backslash \wedge)$ & 9 & $\mathrm{VV} / \mathrm{\Lambda}$ & $r \Delta V$ & $\Delta \wedge \vee$ & $r \cdot 14-199 V$ & Marburg \\
\hline$(19)$ & 10 & $F \mid / G F$ & $1 \pi 9 \Delta$. & 11.90 & $r \cdot 11-199 V$ & Ebola \\
\hline$(Y \cdot)$ & 1 & $\Delta V$ & r & v & $r \cdot 1 r-199 r$ & Hendra \\
\hline$\left(\varphi^{q}\right)$ & rq & $9 / 9$ & VVF & 1.99 & $r \cdot r-r \cdot r$ & SARS-CoV-1 \\
\hline$(r)$ & 1 & $\cdot / \cdot V$ & $v \Delta \cdots$ & $1 \cdots / 0 \mathrm{M}$ & $r \cdot \mid \Lambda-r \cdot \cdot q$ & H1N1 Flu \\
\hline ( & rV & $r y / F$ & 199 & rDI9 & $r \cdot r \cdot-r \cdot 1 r$ & MERS-CoV \\
\hline$(1 \cdot)$ & rit & $f / q$. & $\Delta \cdot \Lambda \cdot \Delta \Delta$ & 1. rDVGG & دسامبر 9 •• تا ا زوئيه •r.r. & COVID-19 \\
\hline
\end{tabular}


سالمند، ريسك خطر مرگ در افرادى كه بيماريهاى زمينه اى ماند

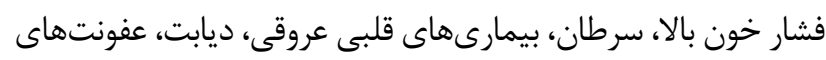

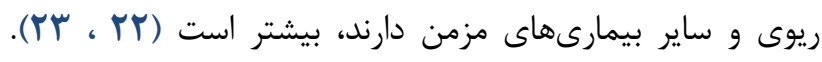

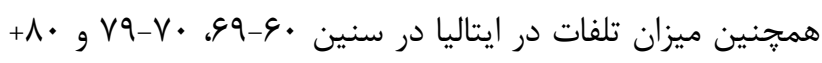

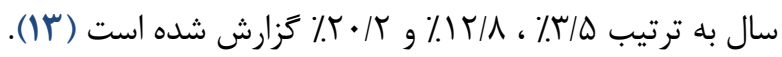

با توجه به شكل \& نتايج بررسى ها در مورد FF\&Y ابتلاى

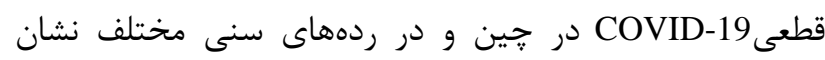

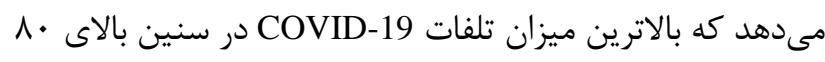

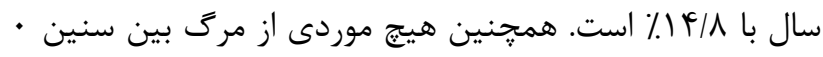

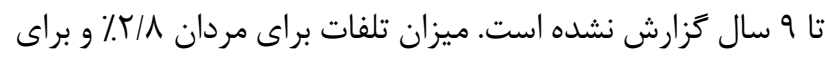

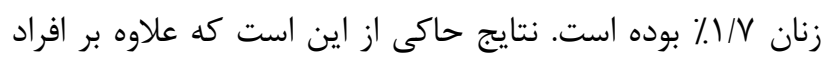

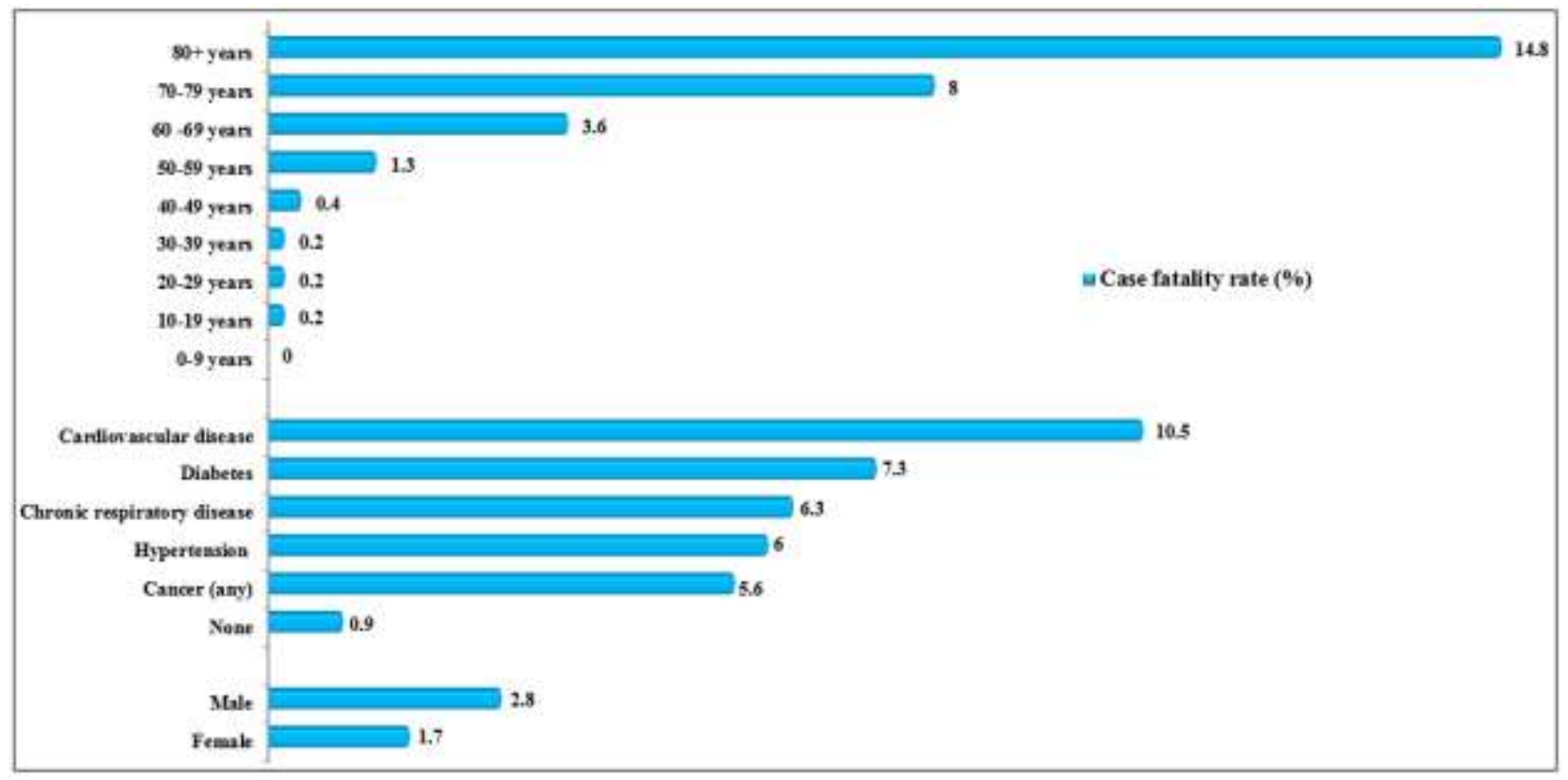

شكل F. ميزان تلفات مربوط به COVID-19 در كروههاى مختلف.

در سنين بالاى • ه سال ززارش شده است (ه). برخى از شباهتها

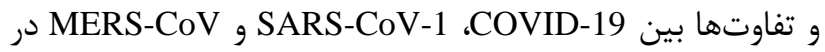
جدول r نمايش داده شده است.

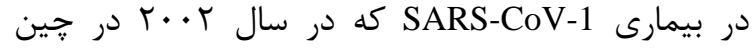
كسترش يافت، ميزان تلفات در گروههاى سنى •-_F

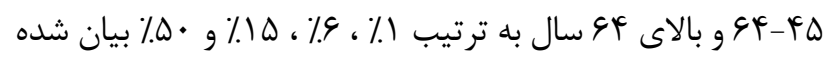
است (YF) و همٍنين بالاترين ميزان تلفات براى MERS-CoV

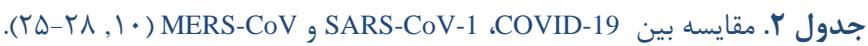

\begin{tabular}{|c|c|c|c|}
\hline COVID-19 & MERS-CoV & SARS-CoV-1 & \\
\hline دسامبر 19 •r در جين & سيتامبر r| إr در عربستان سعودى & 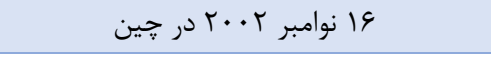 & 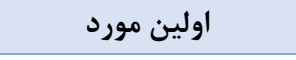 \\
\hline SARS-CoV-2 & MERS-CoV & SARS-CoV-1 & 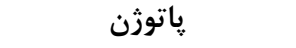 \\
\hline گونهاى از خفاشها و يا مور جهاخوار & 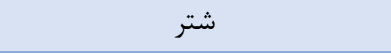 & كونهاى از خفاشها & ميزبان \\
\hline RNA ويروس RA & RNA ويروس RN & RNA ويروس RN & نوع ويروس \\
\hline بتا كروناويروس & بتا كروناويروس & بتا كروناويروس & نوع پياتوزنى \\
\hline 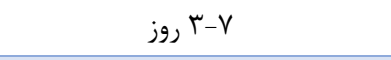 & 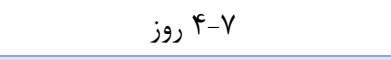 & 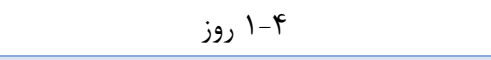 & دوره كمون \\
\hline T.V:I & T.T:I & I:I.ro & نسبت بيمارى مرد به زن \\
\hline تب، سرفه، تنكى نفس & تب، سرفه و تنكَى نفس & تب، سرفه، درد عضلانى، تنگىى نفس و اسهال & 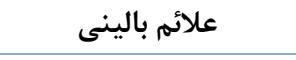 \\
\hline
\end{tabular}




\section{علائم COVID-19}

اشتباه بخيرند و اين موضوع باعث مر اجعهُ آنها به بيمارستانها شود،

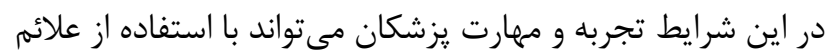

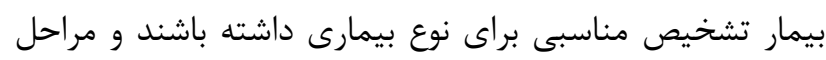

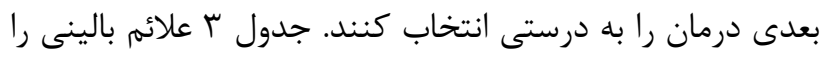

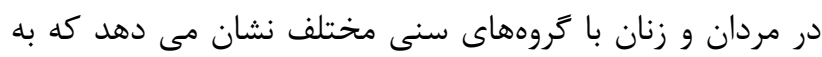
SARS-CoV-2
نشانهاى اوليهاى كه در بين مبتلايان COVID-19 شايعتر

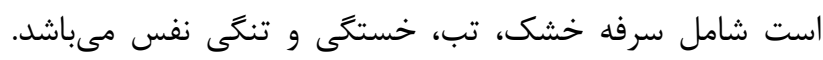
همجنين در برخى از مشاهدات بالينى علائمى مانند عطسه،

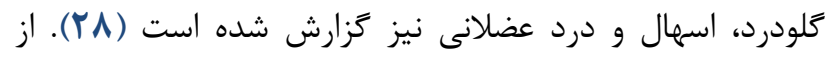

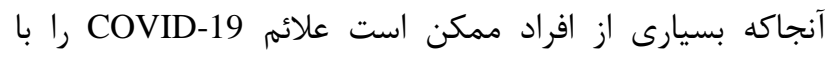

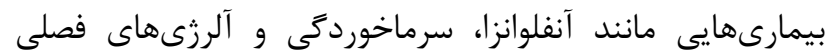

جدول r. مشخصات بالينى بيماران مبتلا به SARS-CoV-2.

\begin{tabular}{|c|c|c|c|c|c|c|c|}
\hline$(\mathbf{M P})$ & $(r r)$ & $(Y Y)$ & $(\mathrm{r} \wedge)$ & (rl) & $(r \cdot)$ & (५१) & مراجع \\
\hline $\begin{array}{l}32 \text { Male- } \\
37 \text { Female }\end{array}$ & $\begin{array}{l}71 \text { Male- } \\
69 \text { Female }\end{array}$ & $\begin{array}{l}75 \text { Male- } \\
63 \text { Female }\end{array}$ & $\begin{array}{l}30 \text { Male- } \\
11 \text { Female }\end{array}$ & $\begin{array}{l}67 \text { Male- } \\
32 \text { Female }\end{array}$ & $\begin{array}{l}19 \text { Male- } \\
32 \text { Female }\end{array}$ & $\begin{array}{l}459 \text { Male- } \\
640 \text { Female }\end{array}$ & جنس \\
\hline $42(35-62)$ & $57(25-87)$ & $56(42-68)$ & $49(41-58)$ & $55(21-82)$ & $45(34-51)$ & 47 (35-58) & ميانگين سنى \\
\hline $60(78 \%)$ & $\begin{array}{l}110 / 120 \\
(91.7 \%)\end{array}$ & $136(98.6 \%)$ & $40(98 \%)$ & $82(83 \%)$ & $43(84.3 \%)$ & $966(87.9 \%)$ & تب \\
\hline $38(55 \%)$ & $90 / 120(75 \%)$ & $55(59.4 \%)$ & $36(76 \%)$ & $81(82 \%)$ & $38(74.5 \%)$ & $744(67.7 \%)$ & سرفه \\
\hline $29(42 \%)$ & $90 / 120(75 \%)$ & $96(69.6 \%)$ & $18(44 \%)$ & NA & $22(43 \%)$ & $419(38.1 \%)$ & خستخى \\
\hline $20(29 \%)$ & $44 / 120(36.7 \%)$ & $43(31.2 \%)$ & $22 / 40(55 \%)$ & $31(31 \%)$ & $11(21.6 \%)$ & $204(18.6 \%)$ & مشكلات تنفسى \\
\hline $21(30 \%)$ & NA & $48(34.8 \%)$ & $18(44 \%)$ & $11(11 \%)$ & $6(11.8 \%)$ & $163(14.8 \%)$ & درد عضلانى \\
\hline $10(14 \%)$ & NA & $9(6.5 \%)$ & $3 / 38(8 \%)$ & $8(8 \%)$ & $5(9.8 \%)$ & $150(13.6 \%)$ & سردرد \\
\hline $7(10 \%)$ & $17 / 139(12.2 \%)$ & $55(39.9 \%)$ & NA & NA & NA & NA & كم اشتهايى \\
\hline NA & NA & $37(26.8 \%)$ & $11 / 39(28 \%)$ & NA & NA & $367(33.4 \%)$ & خلط \\
\hline $10(14 \%)$ & $18 / 139(12.9 \%)$ & $14(10.1 \%)$ & $1 / 38(3 \%)$ & $2(2 \%)$ & $4(7.8 \%)$ & $41(3.7 \%)$ & 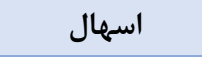 \\
\hline NA & NA & $13(9.4 \%)$ & NA & $9(9 \%)$ & $7(13.7 \%)$ & NA & سر گيجه \\
\hline NA & $24 / 139(17.3 \%)$ & $5(3.6 \%)$ & NA & $1(1 \%)$ & $3(5.9 \%)$ & $55(5 \%)$ & تهوع و استفراغ \\
\hline NA & NA & NA & NA & $4(4 \%)$ & $3(5.9 \%)$ & NA & آبريزش بينى \\
\hline NA & NA & $24(17.4 \%)$ & NA & $5(5 \%)$ & NA & $153(13.9 \%)$ & كَلودرد \\
\hline
\end{tabular}

افراد V) يرهيز از حضور در مكانهاى عمومى و شلوغ. شناسايى

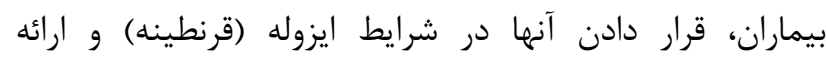

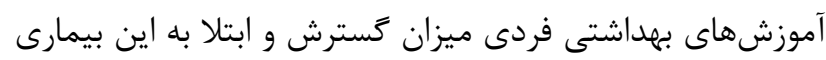

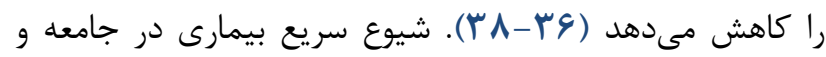
ميزان بالاى واخير بودن آن موجب بروز فشار روانى در بين عموم

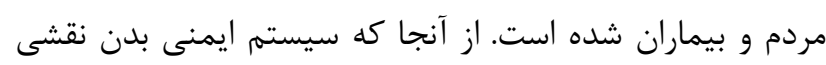

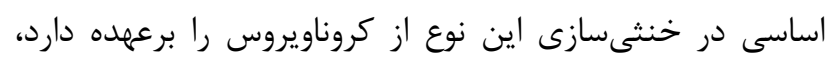
اثرات ناشى از استرس مىتواند سيستم ايمنى را تضعيف كند إند إنى

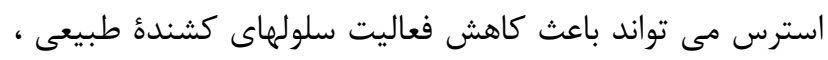
تكثير لنفوسيت ها، توليد آنتى بادى، جمعيت لنفوسيتها و فعال

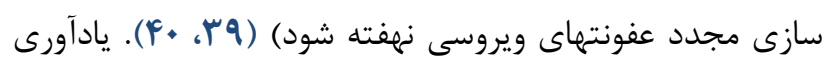

\section{بيشغيرى و درمان بيمارى}

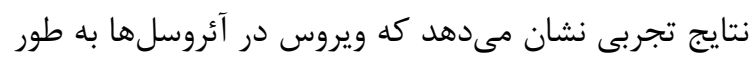
متوسط به مدت دو ساعت و نيه باقى مىماند. اين ماندگارى بر

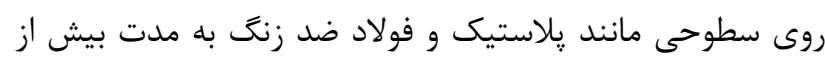

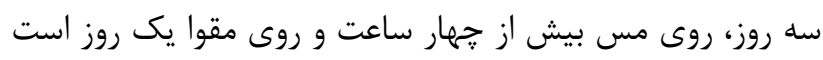
كه اين باعث گسترش سريعتر ويروس و آلوده شدن افراد بيشترى روى

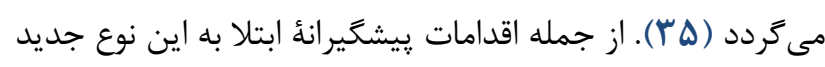
از كروناويروس مى موان به اين موارد اشاره كرد: (1) شستن مدوام

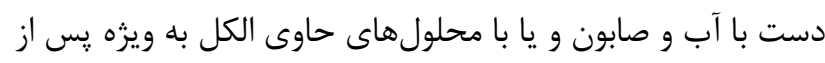

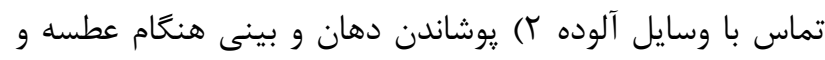

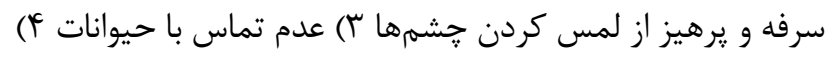
يخت كامل غذاها ه) استفاده از ماسك صورت ؟) حفظ فاصله با 


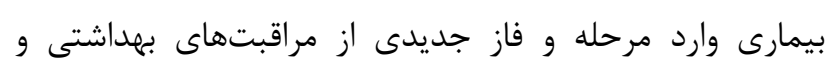

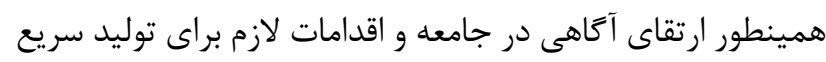

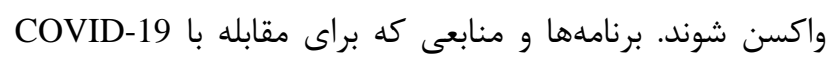

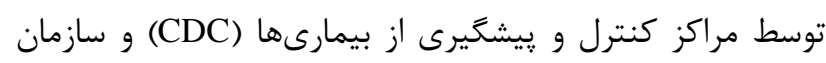

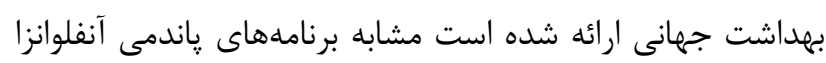

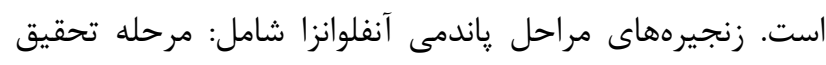

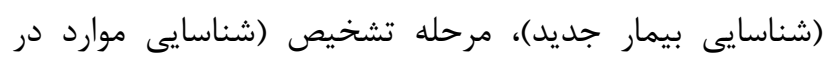

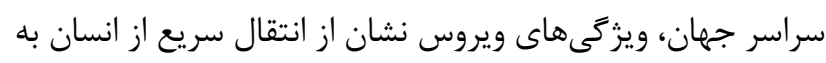

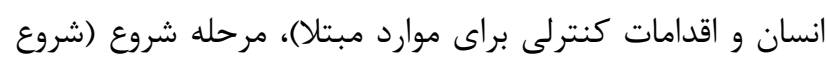

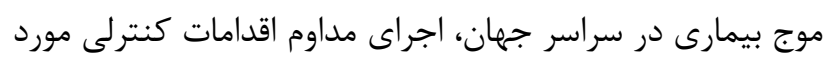

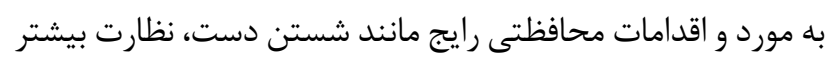

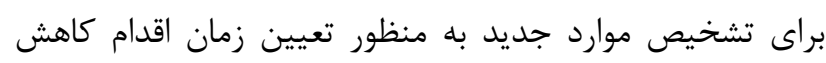

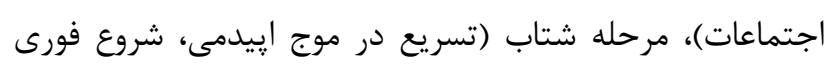

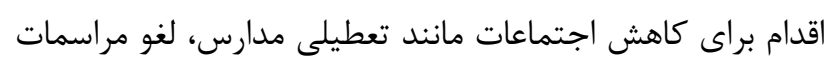

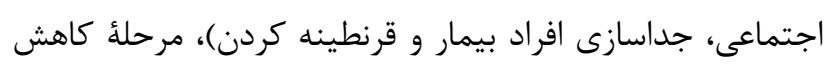

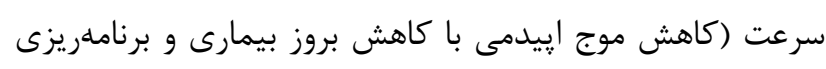

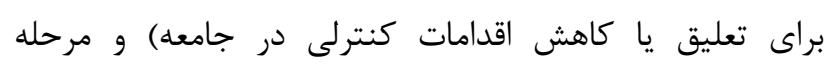

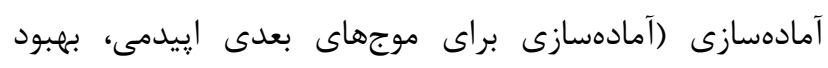

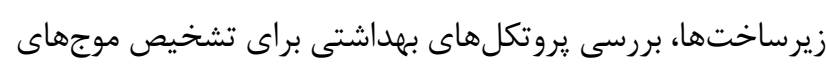

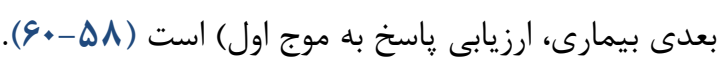

\section{اثرات ويروس كرونا در اقتصاد}

بيمارىهاى عفونى هميشه تأثير منفى بر اقتصات أنصاد جهان

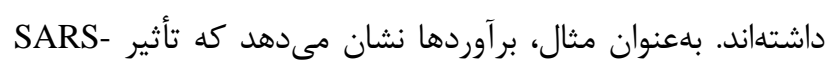

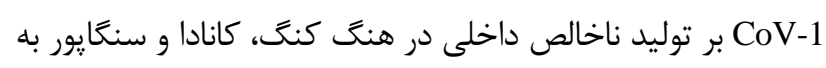

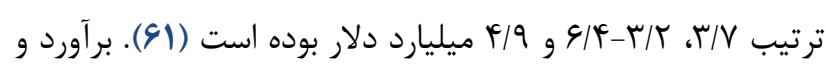

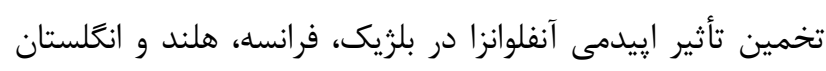

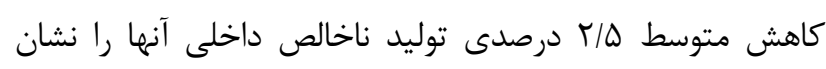

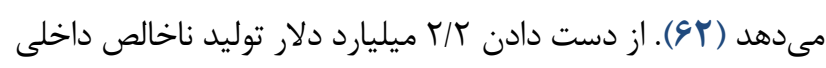

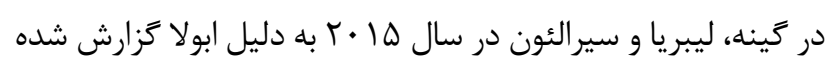

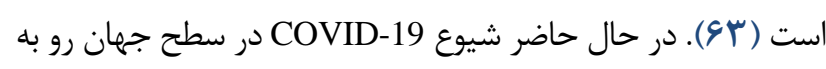
كسترش است و بر روى اقتصاد كشورها تاثير كذاشته است.

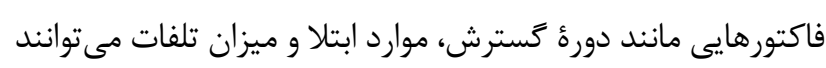

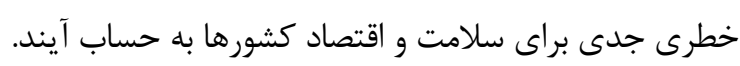

\section{فناورى نانو و كروناويروسها}

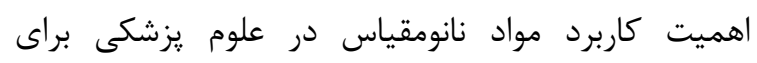
تشخيص و درمان هميشه مورد توجه محققان بوده است (هل (\$).
اين نكته ضرورى است كه مديريت صحيح استرس با استفاده از

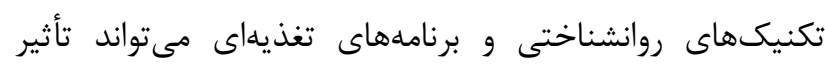

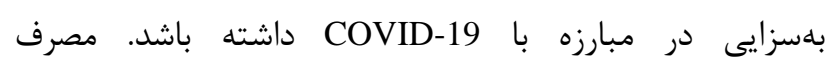

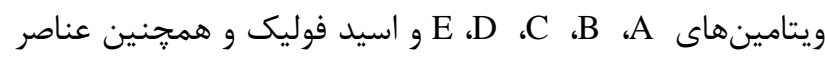
كمياب روى، سلنيوم، آهن و مس از راههاى تقويت سيستم ايمنى

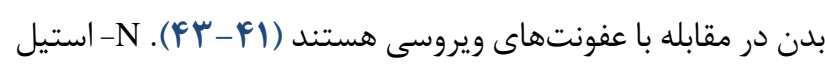

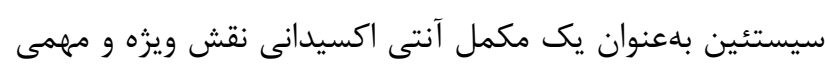

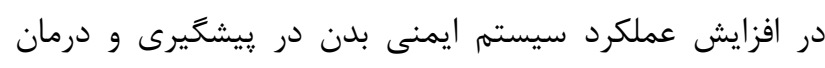

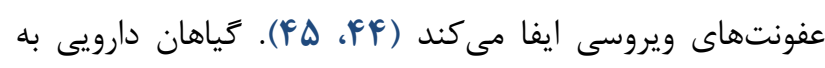

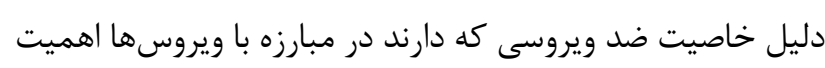

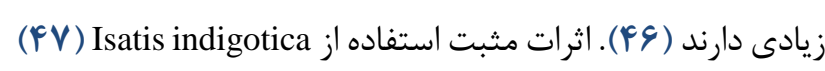

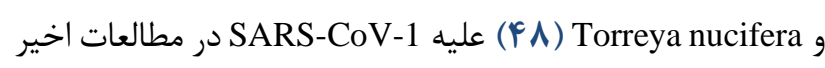
كزارش شده است. در حال حاضر درمان و كاهش عفونت - COVID

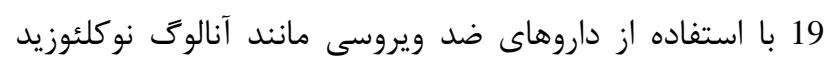

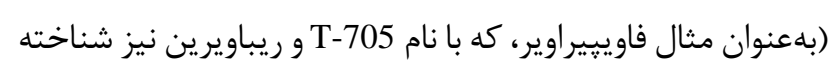
مىشود) و مهار كنندههاى HIV يروتئاز در حال مطالعه و بررسى مئي

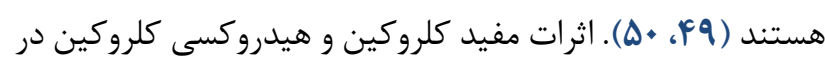

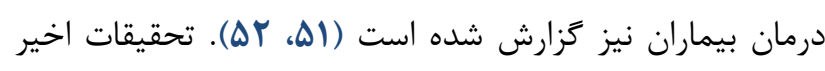

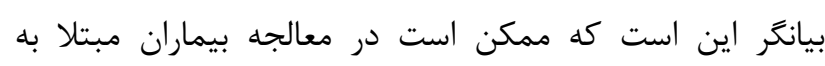

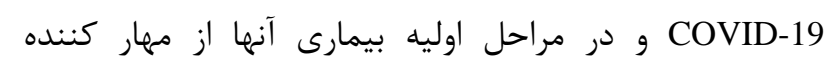
(ACE2)Angiotensin-converting enzyme 2 اصلاح شده زنتيكى از ACE2 به نام محلول نوتركيب انسانى (hrsACE2) ACE2

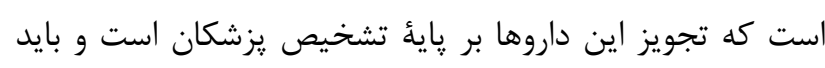

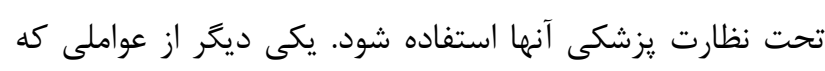

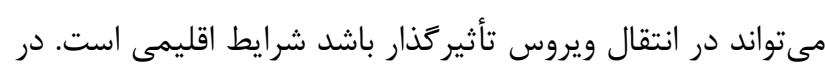

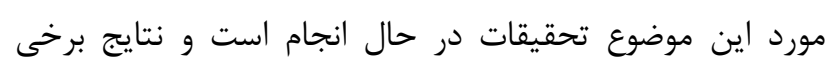

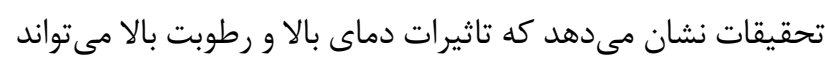

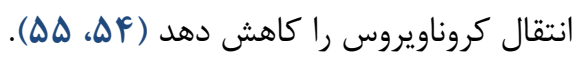

\section{مراحل پِاندمى}

طى سالهاى كذشته، بيماريهاى ويروسى مشترى بين انسان و حيوانات هميشه تهديدى جدى براى سلامتى انسان بوده

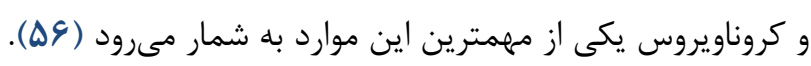
COVID-19

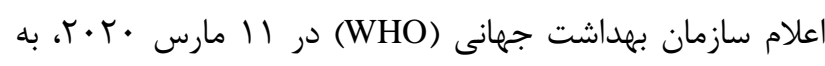

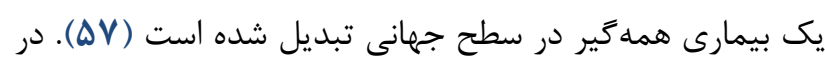

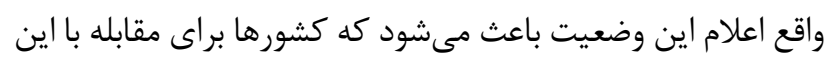


محدوديتهاى دولت در برگزارى گردهمايىهاى اجتماعى و

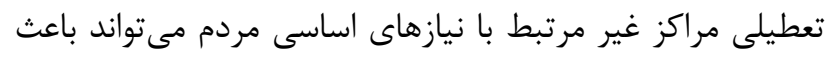
تسطيح و صاف شدن منحنى، كاهش موجهاى بيمارى و كاهش فشار بر سيستم بهداشتى شود. توجه به اين نكته ضرورى است كاس كه

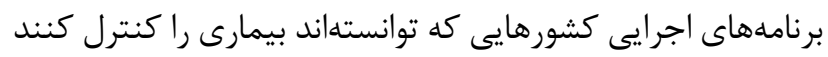

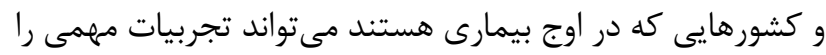
در اختيار كشورهايى كه در مراحل اوليه بيمارى هستند قرار دهد. درواقع محققان كشورهايى كه تحت تاثير اين بيمارى قرار

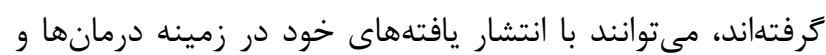
اقدامات كنترلى از وقوع رويدادهاى فاجعه آميز در كشورهاى ديكر

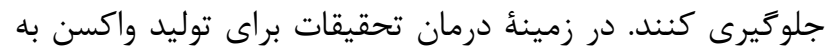

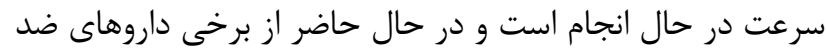
ويروسى و مكملهاى غذايى براى درمان COVID-19 استفاده مىشود. استفاده از مكمل هاى غذايى دو جنبه دارد: (1) تقويت بدن

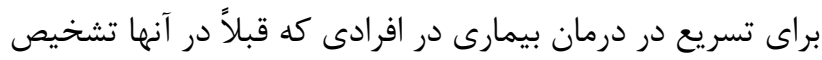

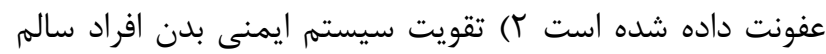
بهمنظور كاهش خطر ابتلا به اين بيمارى. يكى از راههايى كه

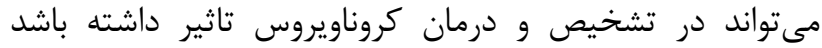

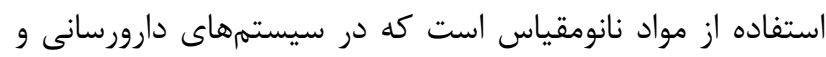
ساخت حسكرها استفاده مىشود. SARS-CoV-2 در تمام نقاط ناط جهان كسترش يافته و همأ كشورها را به خالش كشيده است. توليد و معرفى واكسن و همجنين تغييرات اقليمى، دو سناريويى هستند كه در كنار ساير اقدامات براى كاهش و كنترل - COVID

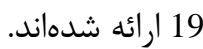

$$
\text { تعارض در منافع }
$$

نويسندكان هيجگَّنه تضاد منافعى اعلام نكردهاند.

\section{Referance}

1. Woo P, Lau S, Lam C, Lau C, Tsang A, Lau J, et al. Discovery of seven novel Mammalian and avian coronaviruses in the genus deltacoronavirus supports bat coronaviruses as the gene source of alphacoronavirus and betacoronavirus and avian coronaviruses as the gene source of gammacoronavirus and deltacoronavirus. Journal of virology.

2012;86(7):3995-4008.

[DOI:10.1128/JVI.06540-11] [PMID] [PMCID]
ويروسها يكى از انواع ميكروبها در اندازه نانومترى هستند و

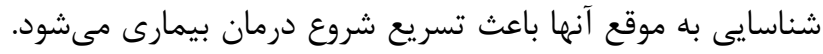

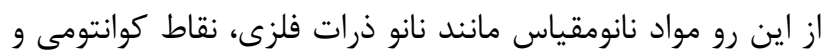

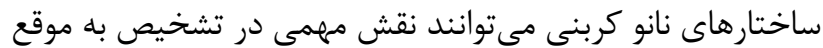

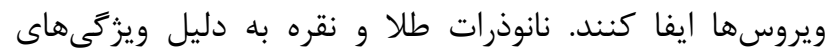
منحصر به فرد و خاص نورى، فيزيكى و شيميايى كه دارند، هميشه مورد توجه محققان در زمينهُ تشخيص و درمان بيمارى بودهاند

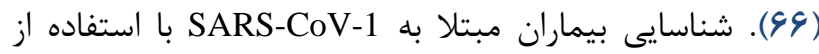

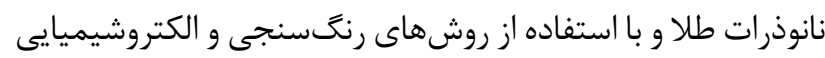
در ه و • إI دقيقه، باعث تسريع در تشخيص بيمارى شده است (91 ، 9V)

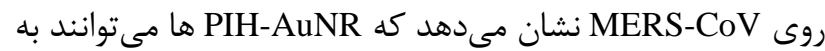
درمان بيمارى كمى كنند (محرك درمان بيمارى باشند) (99).

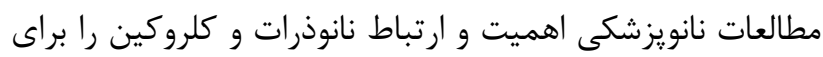
درمان COVID-19 را نشان مىدهد (•V).

\section{نتيجه}

به دليل شيوع سريع COVID-19 در سراسر جهان و افزايش

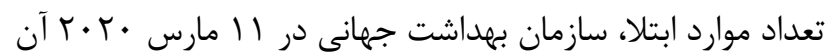
را بهعنوان يك بيمارى همه كير جهانى اعلام كرده است. سرعت بـان

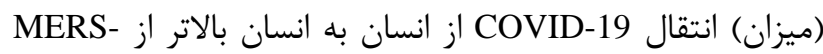

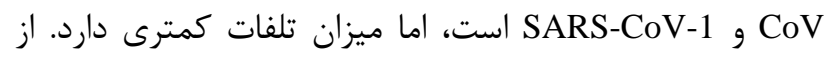
جمله مهمترين عوامل در جلوگيرى از شيوع SARS-CoV-2 اقدامات كنترلى در سطح جامعه و رعايت مراقبتهاى بهداشتى

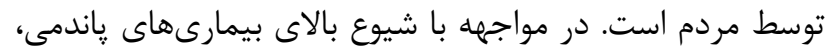

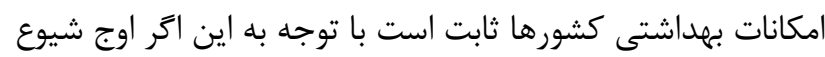
بيمارى بالاتر از سطح امكانات بهداشتى باشد، مراقبت از بيماران

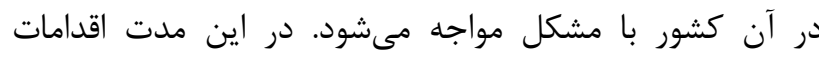
ييشخيرانه و كنترلى مانند رعايت فاصله اجتماعى و و اعمال

2. Li G, Fan Y, Lai Y, Han T, Li Z, Zhou P, Pan P, Wang W, Hu D, Liu X, Zhang Q. Coronavirus infections and immune responses. Journal of medical virology. 2020 Apr;92(4):424-32.

3. Chen L, Liu W, Zhang Q, Xu K, Ye G, Wu W, et al. RNA based mNGS approach identifies a novel human coronavirus from two individual pneumonia cases in 2019 Wuhan outbreak. Emerging Microbes \& Infections. 2020;9(1):313-9. [DOI:10.1080/22221751.2020.1725399] [PMID] [PMCID] 
4. World Health Organization. Summary of probable SARS cases with onset of illness from 1 November 2002 to $31 \quad$ July 2003. https://wwwwhoint/csr/sars/country/table2004_04_2 1/en/. 2020.

5. World Health Organization. MERS situation update January 2020. http://wwwemrowhoint/healthtopics/mers-cov/mers-outbreakshtml. 2020.

6. Zhu N, Zhang D, Wang W, Li X, Yang B, Song J, et al. A novel coronavirus from patients with pneumonia in China, 2019. New England Journal of Medicine. 2020. [DOI:10.1056/NEJMoa2001017] [PMID] [PMCID]

7. Chan JF-W, Kok K-H, Zhu Z, Chu H, To KK-W, Yuan S, et al. Genomic characterization of the 2019 novel human-pathogenic coronavirus isolated from a patient with atypical pneumonia after visiting Wuhan. Emerging Microbes \& Infections. 2020;9(1):221-36. [DOI:10.1080/22221751.2020.1719902] [PMID] [PMCID]

8. Zhou P, Yang X-L, Wang X-G, Hu B, Zhang L, Zhang $\mathrm{W}$, et al. A pneumonia outbreak associated with a new coronavirus of probable bat origin. Nature. 2020:1-4.

9. Lam TT-Y, Shum MH-H, Zhu H-C, Tong Y-G, Ni XB, Liao Y-S, et al. Identification of 2019-nCoV related coronaviruses in Malayan pangolins in southern China. bioRxiv. 2020. [DOI:10.1101/2020.02.13.945485]

10. World Health Organization. Coronavirus disease (COVID-2019) situation reports https://wwwwhoint/emergencies/diseases/novelcoronavirus-2019/situation-reports/. 2020.

11. Wilder-Smith A, Chiew CJ, Lee VJ. Can we contain the COVID-19 outbreak with the same measures as for SARS? The Lancet Infectious Diseases. 2020. [DOI:10.1016/S1473-3099(20)30129-8]

12. Wu JT, Leung K, Leung GM. Nowcasting and forecasting the potential domestic and international spread of the 2019-nCoV outbreak originating in Wuhan, China: a modelling study. The Lancet. 2020;395(10225):689-97. [DOI:10.1016/S01406736(20)30260-9]

13. Onder G, Rezza G, Brusaferro S. Case-fatality rate and characteristics of patients dying in relation to COVID-19 in Italy. JAMA. 2020. [DOI:10.1001/jama.2020.4683] [PMID]

14. Stafford N. Covid-19: Why Germany's case fatality rate seems so low. BMJ. 2020;369:m1395. [DOI:10.1136/bmj.m1395] [PMID]

15. Roser M, Ritchie H, Ortiz-Ospina E. Coronavirus Disease (COVID-19)-Statistics and Research. Our World in Data. 2020.
16. Marston HD, Folkers GK, Morens DM, Fauci AS. Emerging viral diseases: confronting threats with new technologies. Science Translational Medicine. 2014;6(253):253ps10-ps10. [DOI:10.1126/scitranslmed.3009872] [PMID]

17. Gates B. The Next Epidemic - Lessons from Ebola. New England Journal of Medicine. 2015;372(15):1381-4. [DOI:10.1056/NEJMp1502918] [PMID]

18. World Health Organization. Marburg virus disease (15 February 2018). https://wwwwhoint/newsroom/fact-sheets/detail/marburg-virus-disease. 2018.

19. World Health Organization. Ebola virus disease (10 February 2020). https://wwwwhoint/news-room/factsheets/detail/ebola-virus-disease. 2020.

20. Centers for Disease Control and Prevention. Hendra Virus Disease (HeV) (March 17, 2014). https://wwwcdcgov/vhf/hendra/indexhtml. 2014

21. Centers for Disease Control and Prevention. The burden of the influenza A H1N1pdm09 virus since the $2009 \quad$ pandemic. https://wwwcdcgov/flu/pandemic-resources/burdenof-h1n1html. 2019.

22. Novel CPERE. The epidemiological characteristics of an outbreak of 2019 novel coronavirus diseases (COVID-19) in China. Zhonghua liu xing bing xue za zhi= Zhonghua liuxingbingxue zazhi. 2020;41(2):145. [DOI:10.46234/ccdcw2020.032]

23. Heymann DL, Shindo N. COVID-19: what is next for public health? The Lancet. 2020. [DOI:10.1016/S0140-6736(20)30374-3]

24. World Health Organization. Update 49 - SARS case fatality ratio, incubation period (7 May 2003). https://wwwwhoint/csr/sarsarchive/2003_05_07a/en/ . 2003.

25. Xu J, Zhao S, Teng T, Abdalla AE, Zhu W, Xie L, et al. Systematic Comparison of Two Animal-toHuman Transmitted Human Coronaviruses: SARSCoV-2 and SARS-CoV. Viruses. 2020;12(2):244. [DOI:10.3390/v12020244] [PMID] [PMCID]

26. World Health Organization. Middle East respiratory syndrome coronaviurs (MERS-CoV) fact sheet. https://wwwwhoint/en/news-room/factsheets/detail/middle-eastrespiratory-syndromecoronavirus-(mers-cov).

27. Virlogeux V, Fang VJ, Park M, Wu JT, Cowling BJ. Comparison of incubation period distribution of human infections with MERS-CoV in South Korea and Saudi Arabia. Scientific reports. 2016;6:35839. [DOI:10.1038/srep35839] [피] [PMCID]

28. Huang C, Wang Y, Li X, Ren L, Zhao J, Hu Y, et al. Clinical features of patients infected with 2019 novel coronavirus in Wuhan, China. The Lancet. 
2020;395(10223):497-506. [DOI:10.1016/S01406736(20)30183-5]

29. Guan W-j, Ni Z-y, Hu Y, Liang W-h, Ou C-q, He J$\mathrm{x}$, et al. Clinical characteristics of 2019 novel coronavirus infection in China. MedRxiv. 2020. [DOI:10.1101/2020.02.06.20020974]

30. Jian-ya G. Clinical characteristics of 51 patients discharged from hospital with COVID-19 in Chongqing, China. medRxiv. 2020.

31. Chen N, Zhou M, Dong X, Qu J, Gong F, Han Y, et al. Epidemiological and clinical characteristics of 99 cases of 2019 novel coronavirus pneumonia in Wuhan, China: a descriptive study. The Lancet. 2020;395(10223):507-13. [DOI:10.1016/S01406736(20)30211-7]

32. Wang D, Hu B, Hu C, Zhu F, Liu X, Zhang J, et al. Clinical characteristics of 138 hospitalized patients with 2019 novel coronavirus-infected pneumonia in Wuhan, China. Jama. 2020. [DOI:10.1001/jama.2020.1585] [PMID] [PMCID]

33. Zhang Jj, Dong X, Cao YY, Yuan Yd, Yang Yb, Yan Yq, et al. Clinical characteristics of 140 patients infected by SARS-CoV-2 in Wuhan, China. Allergy. 2020. [DOI:10.1111/all.14238] [PMID]

34. Wang Z, Yang B, Li Q, Wen L, Zhang R. Clinical Features of 69 Cases with Coronavirus Disease 2019 in Wuhan, China. Clinical Infectious Diseases. 2020. [DOI:10.1093/cid/ciaa272] [PMID] [PMCID]

35. van Doremalen $\mathrm{N}$, Bushmaker $\mathrm{T}$, Morris $\mathrm{DH}$, Holbrook MG, Gamble A, Williamson BN, et al. Aerosol and Surface Stability of SARS-CoV-2 as Compared with SARS-CoV-1. New England Journal of Medicine. 2020. [DOI:10.1101/2020.03.09.20033217]

36. World Health Organization. Updated WHO advice for international traffic in relation to the outbreak of the novel coronavirus 2019-nCoV (24 January 2020). https://wwwwhoint/ith/2020-24-01-outbreak-ofPneumonia-caused-by-new-coronavirus/en/. 2020.

37. Xiang Y-T, Yang Y, Li W, Zhang L, Zhang Q, Cheung $\mathrm{T}$, et al. Timely mental health care for the 2019 novel coronavirus outbreak is urgently needed. The Lancet Psychiatry. 2020;7(3):228-9. [DOI:10.1016/S2215-0366(20)30046-8]

38. Gostin LO, Wiley LF. Governmental Public Health Powers During the COVID-19 Pandemic: Stay-athome Orders, Business Closures, and Travel Restrictions. JAMA. 2020. [DOI:10.1001/jama.2020.5460] [PMID]

39. Marketon JIW, Glaser R. Stress hormones and immune function. Cellular immunology. 2008;252(12):16-26. [DOI:10.1016/j.cellimm.2007.09.006] [PMID]
40. Godbout JP, Glaser R. Stress-induced immune dysregulation: implications for wound healing, infectious disease and cancer. Journal of Neuroimmune Pharmacology. 2006;1(4):421-7. [DOI:10.1007/s11481-006-9036-0] [PMID]

41. Chandra RK. Nutrition and the immune system from birth to old age. European journal of clinical nutrition. 2002;56(3):S73-S6. [DOI:10.1038/sj.ejcn.1601492] [PMID]

42. Calder PC, Kew S. The immune system: a target for functional foods? British Journal of Nutrition. 2002;88(S2):S165-S76. [DOI:10.1079/BJN2002682] [PMID]

43. Marcos A, Nova E, Montero A. Changes in the immune system are conditioned by nutrition. European journal of clinical nutrition. 2003;57(1):S66-S9. [DOI:10.1038/sj.ejcn.1601819] [PMID]

44. De la Fuente M. Effects of antioxidants on immune system ageing. European Journal of Clinical Nutrition. [DOI:10.1038/sj.ejen.1601476] [PMID]

45. De Flora S, Grassi C, Carati L. Attenuation of influenza-like symptomatology and improvement of cell-mediated immunity with long-term Nacetylcysteine treatment. European Respiratory Journal. 1997;10(7):1535-41. [DOI:10.1183/09031936.97.10071535] [PMID]

46. Mukhtar M, Arshad M, Ahmad M, Pomerantz RJ, Wigdahl B, Parveen Z. Antiviral potentials of medicinal plants. Virus research. 2008;131(2):11120. [DOI:10.1016/j.virusres.2007.09.008] [PMID] [PMCID]

47. Lin C-W, Tsai F-J, Tsai C-H, Lai C-C, Wan L, Ho T$\mathrm{Y}$, et al. Anti-SARS coronavirus 3C-like protease effects of Isatis indigotica root and plant-derived phenolic compounds. Antiviral research. 2005;68(1):36-42.

[DOI:10.1016/j.antiviral.2005.07.002] [PMCID]

48. Ryu YB, Jeong HJ, Kim JH, Kim YM, Park J-Y, Kim $\mathrm{D}$, et al. Biflavonoids from Torreya nucifera displaying SARS-CoV 3CLpro inhibition. Bioorganic \& medicinal chemistry. 2010;18(22):7940-7. [DOI:10.1016/j.bmc.2010.09.035] [PMID] [PMCID]

49. Lu H. Drug treatment options for the 2019-new coronavirus (2019-nCoV). Bioscience trends. 2020. [DOI:10.5582/bst.2020.01020] [PMID]

50. Li G, De Clercq E. Therapeutic options for the 2019 novel coronavirus (2019-nCoV). Nature Publishing Group; 2020. [DOI:10.1038/d41573-020-00016-0] [PMID] 
51. Touret F, de Lamballerie $X$. Of chloroquine and COVID-19. Antiviral Research. 2020:104762. [DOI:10.1016/j.antiviral.2020.104762] [ [PMCID]

52. Colson P, Rolain J-M, Lagier J-C, Brouqui P, Raoult D. Chloroquine and hydroxychloroquine as available weapons to fight COVID-19. Int $\mathrm{J}$ Antimicrob Agents.

2020;105932. [DOI:10.1016/j.ijantimicag.2020.105932] [PMID] [PMCID]

53. Monteil V, Kwon $\mathrm{H}$, Prado $\mathrm{P}$, Hagelkrüys A, Wimmer RA, Stahl M, et al. Inhibition of SARSCoV-2 infections in engineered human tissues using clinical-grade soluble human ACE2.

54. Wang J, Tang K, Feng K, Lv W. High Temperature and High Humidity Reduce the Transmission of COVID-19. Available at SSRN 3551767. 2020. [DOI:10.2139/ssrn.3551767]

55. Oliveiros B, Caramelo L, Ferreira NC, Caramelo F. Role of temperature and humidity in the modulation of the doubling time of COVID-19 cases. medRxiv. 2020:2020.03.05.20031872. [DOI:10.1101/2020.03.05.20031872] [PMCID]

56. Wang L, Crameri G. Emerging zoonotic viral diseases. Rev sci tech Off int Epiz. 2014;33(569-81). [DOI:10.20506/rst.33.2.2311] [PMID]

57. World Health Organization. WHO DirectorGeneral's opening remarks at the media briefing on COVID-19 - $11 \quad$ March 2020. https://wwwwhoint/dg/speeches/detail/who-directorgeneral-s-opening-remarks-at-the-media-briefingon-covid-19---11-march-2020. 2020.

58. Holloway R, Rasmussen SA, Zaza S, Cox NJ, Jernigan DB, Workgroup IPF. Updated preparedness and response framework for influenza pandemics. Morbidity and Mortality Weekly Report: Recommendations and Reports. 2014;63(6):1-18.

59. Centers for Disease Control and Prevention. Pandemic Preparedness Resources. https://wwwcdcgov/coronavirus/2019ncov/php/pandemic-preparedness-resourceshtml. 2016.

60. Organization WH. Key planning recommendations for Mass Gatherings in the context of COVID-19: interim guidance, 19 March 2020. World Health Organization; 2020.

61. Keogh-Brown MR, Smith RD. The economic impact of SARS: how does the reality match the predictions? Health policy. 2008;88(1):110-20. [DOI:10.1016/j.healthpol.2008.03.003] [PMID] [PMCID]
62. Smith RD, Keogh-Brown MR, Barnett T, Tait J. The economy-wide impact of pandemic influenza on the UK: a computable general equilibrium modelling experiment. Bmj. 2009;339:b4571. [DOI:10.1136/bmj.b4571] [PMID] [PMCID]

63. Centers for Disease Control Prevention. Cost of the ebola epidemic. CDC website Updated August. 2016;8.

64. McKibbin WJ, Fernando R. The global macroeconomic impacts of COVID-19: Seven scenarios. 2020. [DOI:10.2139/ssrn.3547729]

65. Wang $\mathrm{X}$, Liu L-H, Ramstroem O, Yan M. Engineering nanomaterial surfaces for biomedical applications. Experimental Biology and Medicine. 2009;234(10):1128-39. [DOI:10.3181/0904-MR-134] [PMID] [PMCID]

66. Larguinho M, Baptista PV. Gold and silver nanoparticles for clinical diagnostics-from genomics to proteomics. Journal of proteomics. 2012;75(10):2811-23. [DOI:10.1016/j.jprot.2011.11.007] [PMID]

67. Mokhtarzadeh A, Eivazzadeh-Keihan R, Pashazadeh P, Hejazi M, Gharaatifar N, Hasanzadeh M, et al. Nanomaterial-based biosensors for detection of pathogenic virus. TrAC Trends in Analytical Chemistry. 2017;97:445-57. [DOI:10.1016/j.trac.2017.10.005] [PMID] [PMCID]

68. Draz MS, Shafiee H. Applications of gold nanoparticles in virus detection. Theranostics. 2018;8(7):1985. [DOI:10.7150/thno.23856] [PMID] [PMCID]

69. Huang X, Li M, Xu Y, Zhang J, Meng X, An X, et al. Novel Gold Nanorod-Based HR1 Peptide Inhibitor for Middle East Respiratory Syndrome Coronavirus. ACS applied materials \& interfaces. 2019;11(22):19799-807. [DOI:10.1021/acsami.9b04240] [PMID]

70. $\mathrm{Hu} \mathrm{TY}$, Frieman M, Wolfram J. Insights from nanomedicine into chloroquine efficacy against COVID-19. Nature Nanotechnology. 2020:1-3. [DOI:10.1038/s41565-020-0674-9] [PMID] [PMCID] 